\title{
Old War, New Deal: Commemorative Landscapes, the National Park Service, and the 75th Anniversary of the Civil War
}

\author{
Rebekah N. Oakes
}

Follow this and additional works at: https://researchrepository.wvu.edu/etd

\section{Recommended Citation}

Oakes, Rebekah N., "Old War, New Deal: Commemorative Landscapes, the National Park Service, and the 75th Anniversary of the Civil War" (2015). Graduate Theses, Dissertations, and Problem Reports. 6335. https://researchrepository.wvu.edu/etd/6335

This Thesis is protected by copyright and/or related rights. It has been brought to you by the The Research Repository @ WVU with permission from the rights-holder(s). You are free to use this Thesis in any way that is permitted by the copyright and related rights legislation that applies to your use. For other uses you must obtain permission from the rights-holder(s) directly, unless additional rights are indicated by a Creative Commons license in the record and/ or on the work itself. This Thesis has been accepted for inclusion in WVU Graduate Theses, Dissertations, and Problem Reports collection by an authorized administrator of The Research Repository @ WVU. For more information, please contact researchrepository@mail.wvu.edu. 
Old War, New Deal: Commemorative Landscapes, the National Park Service, and the $75^{\text {th }}$ Anniversary of the Civil War

\title{
Rebekah N. Oakes
}

Thesis submitted

to the Eberly College of Arts and Science

at West Virginia University

\begin{abstract}
in partial fulfillment of the requirements for the degree of
Master of Arts in

History
\end{abstract}

\author{
Jason Phillips, Ph.D., Chair \\ Melissa Bingmann, Ph.D. \\ Elizabeth Fones-Wolf, Ph.D. \\ Department of History
}

Morgantown, West Virginia

2015

Keywords: Civil War Memory, $75^{\text {th }}$ Anniversary of the Civil War, Civil War Veterans, 1938

Gettysburg Reunion, Gettysburg National Military Park, Fredericksburg and Spotsylvania National Military Park, National Park Service, Civilian Conservation Corps, Great Depression, Cultural Heritage Tourism, Civil War Commemoration, Commemorative Landscapes, Aging Veterans, Franklin D. Roosevelt, Horace M. Albright, James McConaughie, Branch Spalding 


\begin{abstract}
Old War, New Deal: Commemorative Landscapes, the National Park Service, and the $75^{\text {th }}$ Anniversary of the Civil War

\section{Rebekah N. Oakes}

The $75^{\text {th }}$ Anniversary of the American Civil War was both the last major anniversary influenced by living Civil War veterans, and the first commemoration to occur with a number of key Civil War battlefields under the administrative control of the National Park Service. Although largely overlooked by historians, remembrance of the Civil War in the 1930s represented a key transition from commemoration primarily for the veterans of the conflict to a wider commemoration, finding from the Civil War a usable past and a landscape of national memorialization. Through this process, administrative and interpretive shifts changed the very purpose of Civil War battlefields, allowing for broader education and mass tourism. The landscape was also transformed, due to the influx of labor made possible by New Deal programs, into a representation of an idyllic $19^{\text {th }}$ century environment appealing to nostalgic Americans during the tumultuous years of the Great Depression. Finally, commemorative events themselves focused primarily on narratives of bravery, sacrifice, and perseverance, emphasizing the redemption of democracy, and largely ignoring the suffering, sectional bitterness, and racial strife wrought by the Civil War. Despite the presence of veterans at these events, their stories were largely usurped into this larger collective narrative, and the veterans often became sources of amusement or curiosity, even a part of the battlefield landscape itself. This anniversary was an example of the intertwined nature of built commemorative environments and historical memory, as well as an example of aging veterans being appropriated as living monuments. The in-depth analysis of two very different battlefield landscapes, Gettysburg National Military Park and Fredericksburg and Spotsylvania National Military Park, provides a window through which this pivotal transformation can be examined. 


\section{Table of Contents}

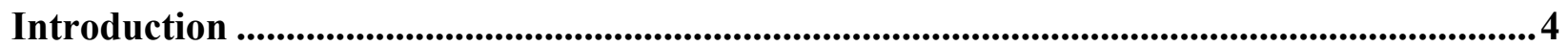

Chapter 1: "There is Nothing so American as our National Parks:" A Shifting Administration for Civil War Battlefields .14

Chapter 2: "The Work Has Only Begun:" Transforming a Commemorative

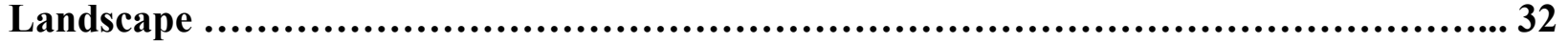

Chapter 3: "There's Still Life in the Old Boys Yet:" Veterans, Living Monuments, and

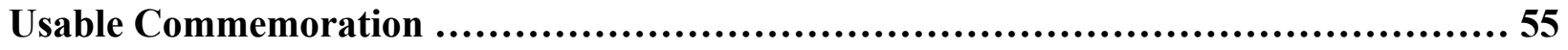

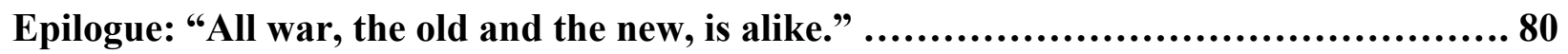

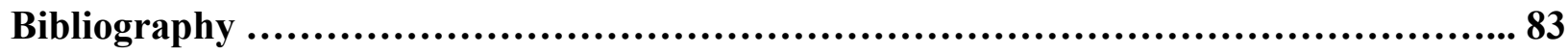




\section{Introduction}

A crowd of one hundred and fifty thousand stood sweltering under the afternoon sun on July 3, 1938. They were so densely packed that police had to attempt to relieve their discomfort, and many fainted and had to be carried off to first aid stations set up close by. Under a shelter of crisp white canvas, around 1,800 elderly Civil War veterans waited in relative comfort. The location of this spectacle was Gettysburg, Pennsylvania, specifically the section of the battlefield known as Oak Hill. This massive crowd was not only waiting for a speech by President Franklin Roosevelt, but also the unveiling of the Eternal Light Peace Memorial, the singular monument to be dedicated during the $75^{\text {th }}$ Anniversary of the battle. Two veterans, Confederate A.G. Harris, aged 91, and George N. Lockwood, his 92-year-old counterpart in blue, dropped an enormous American flag to reveal an imposing fifty-one foot tower of white marble. The crowd erupted into thunderous applause as the bronze urn topping the monument was lit, symbolizing enduring peace. However, this dedication was not singularly about past events. In his speech, the president urged those present to "preserve under the changing conditions of each generation the people's government for the people's good."1 Roosevelt's ability to use commemoration of the Civil War as a way not only to discuss current national struggles, but also to look towards America's future, was the result of the creation of both a national narrative and a commemorative environment which made Civil War battles relevant to the average 1930s American.

The $75^{\text {th }}$ Anniversary of the American Civil War was both the last major anniversary influenced by living Civil War veterans, and the first commemoration to occur with a number of key Civil War battlefields under the administrative control of the National Park Service. Although largely overlooked by historians, remembrance of the Civil War in the 1930s

\footnotetext{
${ }^{1}$ W.A. MacDonald, “150,000 Hear Him,” New York Times, July 4, 1938. ProQuest Historical Newspapers: Accessed January 12, 2015.
} 
represented a key transition from commemoration primarily for the veterans of the conflict to a wider commemoration, finding from the Civil War a usable past and a landscape of national memorialization. Through this process, administrative and interpretive shifts changed the very purpose of Civil War battlefields, allowing for broader education and mass tourism. The landscape was also transformed, due to the influx of labor made possible by New Deal programs, into a representation of an idyllic $19^{\text {th }}$ century environment appealing to nostalgic Americans during the tumultuous years of the Great Depression. Finally, commemorative events themselves focused primarily on narratives of bravery, sacrifice, and perseverance, emphasizing the redemption of democracy, and largely ignoring the suffering, sectional bitterness, and racial strife wrought by the Civil War. Despite the presence of veterans at these events, their stories were largely usurped into this larger collective narrative, and the veterans often became sources of amusement or curiosity, even a part of the battlefield landscape itself. This anniversary was an example of the intertwined nature of built commemorative environments and historical memory, as well as an example of aging veterans being appropriated as living monuments.

To explore the significance of the $75^{\text {th }}$ Anniversary on battlefields under the administrative control of the National Park Service, the examination of two particular battlefields allow for in-depth case studies. Gettysburg National Military Park and Fredericksburg and Spotsylvania National Military Park had vastly different histories before the NPS, but exhibit some of the same primary concerns and interpretive shifts in the 1930s. Contrasting a northern and a southern battlefield, one with a lengthy history of federal control and another with a much shorter relationship with the United States government, the similarities between the development and transformation of these two battlefields in the 1930s are even more profound. The administration, landscape development, and commemorative efforts of each park will be 
analyzed in the following chapters, revealing specific dissimilarities but also abundant parallels. Additionally, the effects of politicians at the federal and park level, enrollees in the Civilian Conservation Corps, veterans of the conflict, and the tourists themselves had on battlefield transformations will be investigated throughout this work.

While Civil War memory and commemoration are relatively new topics of study, this field has greatly expanded in the past few decades, and many of the topics relating to it have been competently and extensively covered. Therefore, the existing historiography provides a strong framework in which to base this research. In the late 1860 s and 1870 s, the majority of veterans were focused on creating new lives in the post-war world. Therefore, northern and southern women spearheaded many of the commemorative efforts in the immediate post-war years. ${ }^{2}$ However, as veterans aged and memories became more distant, battlefield sites became increasingly popular locations for regimental reunions and monument building. In conjunction was the emergence of large veterans organization such as the Grand Army of the Republic (GAR) for Union veterans and the United Confederate Veterans (UCV) in the South. At this point, the GAR was a biracial organization which both commemorated the Emancipation Proclamation and the service of African American veterans. Works such as Caroline Janney's Burying the Dead But Not the Past: Ladies' Memorial Associations and the Lost Cause (2008) and David Blight's Race and Reunion: The Civil War in American Memory and Beyond the Battlefield: Race, Memory, \& the American Civil War extensively cover this transformative early period.

Commemoration by former Confederate soldiers and their descendants also contained a powerful ideological component, which influenced Civil War memory for decades. Confederate

\footnotetext{
${ }^{2}$ David W. Blight, Beyond the Battlefield: Race, Memory, \& the American Civil War (Amherst: University of Massachusetts Press, 2002), 177.
} 
memory of the Civil War centered on the myth of the Lost Cause. Faced with the stark failure of the Confederacy's war aims in 1865, the "architects" of what would become known as the Lost Cause sought to justify their wartime actions as well as providing their posterity with a "correct" version of the war. The Lost Cause eventually distanced the Confederate war aims from slavery, painted a counter-narrative of the war as an episode of overt Northern aggression, which the South lost not because of failed tactics but a disparity in resources, and elevated Confederate leaders such as Robert E. Lee to the status of national heroes. ${ }^{3}$ The emergence of this narrative has had a lasting effect on not only the Southern, but national, understanding of the Civil War. The Lost Cause is a theme prevalent in almost every work of Civil War memory, and has inspired many individual studies, such as the essays included in Gary W. Gallagher and Alan T. Nolan's The Myth of the Lost Cause and Civil War History.

Another key aspect of Civil War memory was reconciliation, a concept extensively analyzed in Blight's work. Reconciliation was an ideology, focused on the common experiences between the veterans of the blue and gray, that of collective heroism and a shared glorious past. This ideology dominated the fiftieth anniversary "jubilee" of the Battle of Gettysburg, and further emphasized the importance of binding sectional wounds. ${ }^{4}$ Over fifty-five thousand Union and Confederate veterans met at Gettysburg in 1913, listening to speeches that classified the heroism during the battle as "not Southern valor nor Northern valor, but American valor." Echoes of the Lost Cause can be seen in reconciliation, particularly in the near complete removal

${ }^{3}$ Gary W. Gallagher and Alan T. Nolan, eds., The Myth of the Lost Cause and Civil War History (Bloomington: Indiana University Press, 2000), 1-3.

${ }^{4}$ Edward Tabor Linenthal, Sacred Ground: Americans and Their Battlefields, 2nd ed (Urbana: University of Illinois Press, 1993), 95.

${ }^{5}$ Ibid., 96. 
of slavery and African Americans from the standard narrative. ${ }^{6}$ Although this commemoration, and reconciliation as a whole, expands commemoration beyond the local or regional level to encompass a more national audience, it was still largely a veterans' story. The factor that allowed veterans of blue and gray to sideline sectional differences was their shared experience as soldiers, an experience that was not shared by the rest of the nation.

Although the existing historiography is extensive, the $75^{\text {th }}$ Anniversary has often been ignored or oversimplified as nothing more than an extension of the reconciliationist fervor of 1913. The historiography seems to jump directly to the centennial observances in the 1960 s, covered in texts such as Robert Cook's Troubled Commemoration (2007). However, key differences exist between this anniversary and the semicentennial or centennial. Through discussing preparations for the $75^{\text {th }}$ Anniversary commemorations, this work investigates not only persisting reconciliationist attitudes, but also a major shift in the focus of the commemoration that has previously been unexplored. The 1930s mark the first commemorations of the Civil War focusing primarily on the nation as a whole, instead of the veterans. Conservation efforts and infrastructural developments supporting mass tourism allowed for tourists to easily visit the battlefields. This new commemorative landscape, coupled with nostalgia for the past, propelled the Civil War into a role as a national experience, instead of only the experience of the few who had fought decades ago. However, the continued presence of the veterans created a unique situation where two wildly different visions for the commemorative landscape were competing for the same historical space.

Other texts, part of a more recent wave of scholarship regarding historic sites, focus singularly on one battlefield or instance of commemoration, particularly concerning Gettysburg.

\footnotetext{
${ }^{6}$ Blight, Beyond the Battlefield, 182.
} 
Both Gettysburg and Fredericksburg and Spotsylvania have the benefit of excellent administrative histories, written by Harlan Unrau and Joan Zenzen respectively. ${ }^{7}$ Although thorough and clearly written, these texts were primarily produced for internal use, and were not intended to reach a wider audience. Works such as Thomas A. Desjardin's These Honored Dead: How the Story of Gettysburg Shaped American Memory (2003) and Jim Weeks' Gettysburg: Memory, Market, and an American Shrine (2003) analyze Gettysburg as a tourist attraction and in popular culture, but offer limited treatment of the 1930s, and the park's administration in general. A recent work by Jennifer Murray, On A Great Battlefield': The Making, Management, and Memory of Gettysburg National Military Park, 1933-2013 (2014), does provide an excellent analysis of changing administrative imperatives throughout Gettysburg's existence as a national park, and is certainly the definitive work on the subject. However, all of these works treat Gettysburg as a singular case, and not as part of a wider national system of shifting administrative emphasis and changing commemorative landscapes. By comparing even these two parks, this work takes the first step toward treating battlefields in the 1930s holistically, which illuminates the greater significance of this transformative era.

This work will also heavily intersect with the environmental and cultural historiography of the Great Depression and the New Deal, as well as cultural heritage tourism. Many Americans in the 1930s at least partially blamed the economic depression on the careless treatment of environmental resources, which gave birth to a modern conservation movement. Many New Deal

\footnotetext{
${ }^{7}$ See Harlan D. Unrau, "Administrative History: Gettysburg National Military Park and National Cemetery, Pennsylvania" (National Park Service, 1991). http://www.nps.gov/history/history/online_books/gett/adhi.pdf. and Joan M. Zenzen, At the Crossroads of Preservation and Development: A History of Fredericksburg and Spotsylvania National Military Park (Administrative History, August 2011).
} 
programs had a heavy focus on conservation, and the preservation of historic sites was part of this process as well. Texts like Neil Maher's Nature's New Deal: The Civilian Conservation Corps and the Roots of the American Environmental Movement (2012), among others, show that Americans were willing to commit both monetary and labor resources for conservation efforts. I will also explore the tourist's emerging roles as consumers of American culture. Marguerite Shaffer's See America First: Tourism and National Identity, 1880-1940 (2001) provides a basis for understanding the concept of "national tourism" in the early $20^{\text {th }}$ century, a period of time where improved infrastructure and automobile travel allowed for middle-class Americans to use tourism to escape their urban lives, develop their personal and collective identities, and even become better citizens. Utilizing memory studies, environmental history, and cultural heritage tourism will provide a fuller picture of the factors influencing park development.

The first chapter deals with the actual shift in administration from the War Department to the National Park Service, and the cultural and political climate that made this transition possible. This includes background information on America's changing views regarding environmental and historic preservation brought on by the Great Depression, as well as more specific treatment of significant figures such as Franklin Roosevelt and Horace Albright, the second director of the National Park Service who supported the inclusion of historic parks in the system. Histories at the time, such as Douglas Southall Freeman's biography of Robert E. Lee, concentrated on dynamic figures and heroism. This time period also contained great nostalgia for a romanticized view of a bucolic and glorious past driving not only literary representations of the Civil War such as Margaret Mitchell's Gone with the Wind, but also renewed interest in tourism to battlefield sites. Finally, tourism itself was increasing in importance as a way for American citizens not only to escape their increasingly urbanized lives, but also to uncover personal and 
national identities. Demand for tours with less focus on specific information about troop movements and more generalized context, convenient visitor services, and a usable past increased in the early years of the Great Depression, resulting in the transfer of Civil War battlefields from the War Department to the NPS. Interpretive imperatives shifted from the correct marking of the field and the training of current military units to the education of everyday visitors. The Civil War, its veterans, and its landscape became an experience modern Americans could use as a model for society and an example of American perseverance through a difficult time.

The physical transformations to the commemorative landscape brought about in the 1930s are the focus of a second chapter. Through exploring the nature of a built commemorative environment constantly in flux, I will argue that changes in visitor services, road networks, and even tree planting carried a distinct political and environmental message. Since the emphasis of the park administration was to return the battlefields to a $19^{\text {th }}$ century pastoral appearance, while still providing for the convenience of the modern visitor, the landscape of monumentation built by the veterans of the conflict was screened, obscured, or overwhelmed. The result of this dramatic change was increased tourism, much wider contact between the federal government and visitors, and battlefield spaces nearly unrecognizable from just a decade previously. Much of this labor was in preparation for $75^{\text {th }}$ Anniversary events, and carried out by enrollees of New Deal programs such as the Civilian Conservation Corps. Landscape changes and the influx of hundreds of unemployed young men into battlefields and surrounding areas caused tension with both veterans groups and local communities, much of which was ignored in the push for battlefield development. 
The final chapter will focus on the anniversary commemorations themselves, particularly how the ceremonies relegated veterans to the role of living monuments. Ceremonies explored will include the mammoth Blue and Gray reunion at Gettysburg in July of 1938, large events such as the observances at Chancellorsville in 1935, and smaller services such as the dedication of the Stonewall Jackson Shrine in 1937. These commemorations are largely characterized by ardent patriotic fervor, captured through the lenses and microphones of a substantial media presence. Large numbers of tourists journeyed to hear speeches given by historians such as Freeman, watch the dedication of the Eternal Light Peace Memorial at Gettysburg, and cheer the military spectacle of contemporary troops and weaponry recreating moments of Civil War battles. Most significantly, the veterans were included in these ceremonies as the guests of honor, but not as a driving force in the commemoration. Their experience was oversimplified through the language of reconciliation, an overemphasis on age by media outlets, and the misappropriation of the veterans experience for a national message of valor, peace, and enduring democratic principles. Although nearly 10,000 Civil War veterans were still alive at the decade's close, the transformation of the battlefield landscape and tone of the $75^{\text {th }}$ Anniversary commemorations had placed their visions for commemoration firmly into antiquity.

As with any major project, I have incurred many debts of gratitude throughout the research and writing purpose. My thesis committee has been instrumental to the completion of this work. Without Dr. Jason Phillips' constant encouragement, willingness to listen to my brainstorming in the early phases of this project, and assistance with organization, this thesis would be nothing but a bunch of scattered thoughts. Dr. Melissa Bingmann's extremely valuable insight into cultural heritage tourism and sacred space, as well as Dr. Liz Fones-Wolf's knowledge of Great Depression-Era America, were extremely helpful in furthering my analysis 
and placing it into context. I thank my entire committee for their patience and suggestions, and I am looking forward to working with them as this project expands and develops in the future. I am also greatly indebted to John Heiser of Gettysburg National Military Park and Eric Mink at Fredericksburg and Spotsylvania National Military Park for allowing me to explore the Park archives, pointing me in the direction of helpful sources, and keeping these resources organized and available for researchers such as myself. Finally, I would like to thank my parents for being a constant and continued inspiration in both my career and my everyday life. 
Chapter 1: "There is Nothing so American as our National Parks:" A Shifting Administration for Civil War Battlefields

On Sunday, April 9, 1933, Horace Albright was given a monumental opportunity. Quiet and unassuming, the director of the National Park Service was invited to inspect one of the first Civilian Conservation Corps camps stationed in Shenandoah National Park. Accompanying him would be some of the most influential Washington politicians, including the new president, Franklin D. Roosevelt, whose famous first one hundred days in office were well underway. Albright had an agenda aside from reviewing the President's new relief effort; he wanted to convince the president of the need to transfer America's military parks to his own organization. Sensing the president's wish for an informal, enjoyable visit, Albright watched as others irritated Roosevelt by loudly sharing their political opinions. Instead, Albright only commented on what the President was seeing: roads and infrastructure developed by the park service in the last decade. As the entourage passed over the old battlefield of Second Manassas when returning to Washington, Albright seized his chance. Casually asking if Roosevelt know that the famous battle had started on the ground they were currently traversing, he opened up the topic of military parks. Explaining the wastefulness and misuse of military parks under other federal organizations, he made his case for their transfer to the National Park Service, which could afford them the same protection as it did the expanses of American wilderness. Concluding his impromptu speech, Albright firmly stated, "The National Park Service ought to have charge of administering all of those parks. It's right." ${ }^{\prime 1}$ Roosevelt agreed, and because of one car ride, the appearance and interpretation of America's Civil War battlefields was changed forever.

\footnotetext{
${ }^{1}$ Horace M. Albright, as told to Robert Cahn. The Birth of the National Park Service (Salt Lake City, UT: Howe Brothers, 1985), 294-96.
} 
The administrative shift for federally owned Civil War battlefields of the 1930s was possible because of changing national views regarding environmental and historic preservation. Much of this transformation was due to the fledgling but rapidly expanding National Park Service. Established in 1916, this federal organization was primarily dedicated to preserving vast expanses of nature in the American West until 1929. ${ }^{2}$ Initial attempts by the War Department and the Department of the Interior to ensure this transfer occurred were favorably received by Congress. Either administered by the Cemeterial Branch of the War Department, by local entities, or not at all, the executive branch was certain that the Department of the Interior, "specifically created to take care of national parks, was in a position better calculated successfully to do so and was the proper governmental agency to care for the nation's historic shrines." Despite this support, the stock market crash and subsequent economic downturn of 1929, ushering in the Great Depression, delayed this transfer. ${ }^{4}$ However, a new president of the nation and superintendent of the NPS would ensure this delay would not last long.

With the ascension of director Horace Albright, a long-time history enthusiast, the umbrella of the Park Service expanded to include sites of historic significance. ${ }^{5}$ Advancing the argument that "American heritage was made up in equal parts of the unique grandeur of its geography and the heroic deeds of the people," Albright used the 1932 bicentennial of George Washington's birth to incorporate the first president's birthplace, Jamestown, and Yorktown into

\footnotetext{
${ }^{2}$ William C. Everhart, The National Park Service, Westview Library of Federal Departments, Agencies, and Systems (Boulder, Colo: Westview Press, 1983), 21

3 “A New Plan for Our Battle Sites,” New York Times, July 22, 1928. ProQuest Historical Newspapers: Accessed January 12, 2015.

${ }^{4}$ Denise D. Meringolo, Museums, Monuments, and National Parks: Toward a New Genealogy of Public History (Amherst: University of Massachusetts Press, 2012), 96.

${ }^{5}$ Everhart, The National Park Service, 21; Albright, The Birth of the National Park Service, 184.
} 
the National Park system. This action set a standard for other historic parks. ${ }^{6}$ In order to be incorporated into the NPS, historic sites must be considered unique, meaning that they were "points or bases from which the broad aspects of pre-historic and American life can best be presented." Furthermore, included sites were said to be symbolic of a "great idea or ideal" that aided in providing a comprehensive depiction of American history. ${ }^{7}$ Therefore, sites were not only to be preserved, but also to have an educational component. New historic parks were intended to teach Americans about their own history, through which they could derive lessons applicable to contemporary challenges.

Albright found an ally in Franklin Delano Roosevelt. In an address on the parks given in 1934, Roosevelt made the stirring claim that "there is nothing so American as our national parks." " Explaining that the fundamental idea behind the parks, "that the country belongs to the people," the president asserted that adding and preserving parks not only enriched the nation but the lives of its citizens. ${ }^{9}$ Therefore, the inclusion of historic parks and the expansion of the National Park Service was a strong governmental investment in the future. Stating that the NPS was "an example of efficient and far-seeing governmental administration," Roosevelt cited the transfer of historic parks, battlefield sites, memorials and national shrines as evidence of the need for both recreational and educational opportunities. He then invoked the idea of American exceptionalism, stating "no other country in the world has ever undertaken in such a broad way for protection of its natural and historic treasures and for the enjoyment of them by vast numbers

\footnotetext{
${ }^{6}$ Everhart., 22.

${ }^{7}$ Meringolo, Museums, Monuments, and National Parks, 112.

8 “The President's Address on Parks," New York Times, August 6, 1934. PAIS International: Accessed January 12, 2015.

${ }^{9}$ Ibid.
} 
of people." ${ }^{10}$ Not only did the president wish to ensure these historic sites could be accessed by the average citizen, he also wanted to guarantee their relevance. Beyond creating educational opportunities for visiting Americans, the NPS was to aid in fostering a sense of national unity, rooted in a mutual past.

Originally administered by the War Department, Executive Order 6166 reassigned a number of Civil War battlefields to the Park Service on June 10, 1933, a transfer that represented a fundamental shift in the institutional purpose of preserving these battlefields. ${ }^{11}$ Under the War Department, battlefields were primarily used either for documenting the veterans' experience and providing space for their commemoration, or more broadly as training grounds for current military operations. According to Albright, the former administrators of these sites were not interested in catering to tourists, or even necessarily telling the stories of the battlefields. This job largely fell to private guides and local commemorative organizations. ${ }^{12}$ Conversely, Albright saw historical research and education as a programmatic imperative. ${ }^{13}$ Under his tenure, the first National Park Service historical research staff was established in 1933, and the number of historians working for the Park Service grew from three in 1932 until World War II, when the organization was the nation's largest employer of historians. ${ }^{14}$ Two parks exemplifying the challenges and significance of these transformations, while highlighting differences on a park-topark basis, were Gettysburg National Military Park and Fredericksburg and Spotsylvania National Military Park.

\footnotetext{
10 "The President's Address on Parks," New York Times, August 6, 1934. PAIS International, Accessed January 12, 2015.

${ }^{11}$ Meringolo., 111.

12 Ibid.

${ }^{13}$ Ibid., 87.

${ }^{14}$ Everhart, The National Park Service, 54.
} 
By the end of the Civil War, Gettysburg was a place firmly entrenched in the American consciousness. Therefore, the history of memorialization at Gettysburg was longer than most other military parks added to the national park system in 1933, and was a story largely driven by the veterans of the conflict. With the establishment of the national cemetery in November 1863, preservation efforts began almost immediately, and they continued to increase as veterans began holding reunions on the field as early as the late 1860s. By 1880, members of the Grand Army of the Republic had firm control over the Gettysburg Battlefield Memorial Association, resulting in an explosion of monumentation to the Union Army. These stone markers would come to characterize the field. ${ }^{15}$ Gettysburg was established as a military park under the War Department in 1895, largely due to the tireless efforts of eclectic Civil War General Daniel Sickles. It was used not only as a space for veterans' commemoration, but also for contemporary military maneuvers and training. Most educational imperatives were directed towards the marking of the field and studies of troop movements, leaving the education of visitors largely to a growing number of licensed battlefield guides. ${ }^{16}$

Both the veterans and the nation as a whole placed a great amount of symbolic importance on Gettysburg. One reason for this was certainly the sheer amount of bloodshed that occurred among the rolling hills. The "most sanguinary" of Civil War battles, Gettysburg saw an unprecedented 50,000 casualties, therefore epitomizing the idea of valiant sacrifice, which was very attractive to people in the $1930 \mathrm{~s} .{ }^{17}$ Also given great attention was Gettysburg's reputation, real or developed, as where "the southern cause reached its high tide," or the turning point of the

\footnotetext{
${ }^{15}$ Unrau, Administrative History, 45-46.

${ }^{16}$ Unrau, Executive Summary.

17 “A New Plan for Our Battle Sites,” New York Times, July 22, 1928. ProQuest Historical Newspapers: Accessed January 12, 2015.
} 
Civil War. ${ }^{18}$ It is also not insignificant that Gettysburg is a rural and naturally beautiful area of the country. A 1924 publication by veteran Luther W. Minnigh exemplified the unique hold Gettysburg had on popular imagination by stating, "There is one Gettysburg! And it is without doubt the most picturesque and interesting point in America for the tourist, either soldier or citizen, to visit." ${ }^{19}$ Despite having personal experience in the conflict, Minnigh's words speak to the shift in Gettysburg's appeal to a wider public.

This thesis is by far the first work to look at Gettysburg's administration. Jennifer Murray's recent work, On a Great Battlefield: The Making, Management, and Memory of Gettysburg National Military Park, highlights the Great Depression Era as one of the four pivotal eras in the administration of the park. ${ }^{20}$ Her treatment of the 1930 s and the administrative shift to the National Park Service is an outstanding section in what is certainly the definitive work on Gettysburg park history. In both her monograph and her article, “'Far Above Our Poor Power to Add or Detract: National Park Service Administration of the Gettysburg Battlefield, 1933-1938," Murray draws many of the same conclusions as this chapter. ${ }^{21}$ Murray and other previous works tend to treat Gettysburg as a singular case study instead of as part of a wider shift toward a new battlefield commemoration. However, trends at Gettysburg were not unique. Juxtaposing Gettysburg with even one other battlefield illuminates that despite the primacy given to the great Pennsylvania killing field, the events at Gettysburg in the 1930s did not occur in a

\footnotetext{
18 "A New Plan for Our Battle Sites."

${ }^{19}$ Luther W. Minnigh, Gettysburg: What They Did Here (Gettysburg, PA: Tipton and Blocher, 1924), 133.

${ }^{20}$ Jennifer Marie Murray, “'On A Great Battlefield': The Making, Management, and Memory of Gettysburg National Military Park, 1933-2013” (Knoxville: University of Tennessee Press, 2014), 5.

${ }^{21}$ Jennifer M. Murray, "'Far Above Our Poor Power to Add or Detract: National Park Service Administration of the Gettysburg Battlefield, 1933-1938," Civil War History 55 (March 2009): 67-68.
} 
commemorative vacuum. Looking at battlefields holistically as a system will allow for a more nuanced interpretation of commemorative landscapes in the future.

As a southern battlefield area with little influence from the federal government for much of its history, Fredericksburg and Spotsylvania's trajectory was very different. Containing the battlefields of Fredericksburg, Chancellorsville, the Wilderness, and Spotsylvania Court House, this new park was much more expansive, and therefore different types of infrastructural challenges existed. The history of federal involvement in commemoration was also significantly shorter than at Gettysburg. Fredericksburg and Spotsylvania was not established as a federal military park until 1927, as the government was initially primarily concerned with preserving Union victories. Therefore, local veterans and interest groups undertook much of the early commemoration. Memorial day commemorations were highly significant to the local community, as were speeches by prominent Confederate veterans such as John Goolrick. However, attempts by local entities to promote outside tourism were largely failures, and the community supported the War Department's influence, particularly out of fear of the possibility of losing the land. In the 1920s, the area faced the very real concern of modern encroachments. ${ }^{22}$

Like Gettysburg, the ground encompassed by Fredericksburg and Spotsylvania was some of the bloodiest in North America; 100,000 casualties fell during the four battles interpreted by the park. However, these engagements occurred miles away from one another over an eighteenmonth period in a rapidly developing area between the urban metropolises of Washington D.C. and Richmond, Virginia. ${ }^{23}$ Preservation was understandably more of a challenge. Although "the State of Virginia and local organizations did much to preserve some of the sites," funding issues prevented preservation, infrastructural changes, and educational improvements on a large scale

\footnotetext{
${ }^{22}$ Zenzen, 15-28.

${ }^{23}$ Ibid., 3.
} 
until the War Department, and later the National Park Service, took control of the site. ${ }^{24}$ The historic significance of this ground was publicized to tourists through maps and articles dealing with Virginia's historic sites. Under the heading "Scenes of the Nation's Birth and Survival," which highlighted the American Revolution and the Civil War as two of the pinnacle formative events in the nation's history, Fredericksburg and the surrounding battlefield areas are labeled on a tourist route map as "very historic." ${ }^{25}$ Plans in the early 1930s included instituting a proper roads system, not just to one or two specific battlefield highlights but also to the entire field. Also a priority for the War Department was the correct marking of the field, and R. Walton Moore, one of three men chosen for the War Department's park commission, predicted in 1931 that "there will be a great many monuments commemorating officers of distinction who fell and the exploits of various units which were engaged." ${ }^{26}$ However, the battlefields were transferred to the NPS two years later, and the primary focus of interpretation shifted to the education of the average visitor.

Developments at Gettysburg mirrored the National Park Service's emerging dedication to research and education. In 1935, superintendent James McConaughie explained, "While the park was under the War Department little effort was made toward promoting an educational program. Their effort was directed at correct marking of the field. ${ }^{, 27}$ Determinately stating that this had been adequately accomplished, McConaughie shifted the park's focus towards educational programming. The 1930s marked the expansion of Gettysburg's historical

24 “A Virginia Battle Zone Wins Late Recognition," New York Times, August 30, 1931. ProQuest Historical Newspapers: January 12, 2015.

${ }^{25}$ Leon A. Dickinson, “Motoring In Historic Virginia," New York Times, April 3, 1932. ProQuest Historical Newspapers: Accessed January 12, 2015.

26 "A Virginia Battle Zone Wins Late Recognition."

${ }^{27}$ Department of the Interior, National Park Service, "Superintendent's Annual Report for the Year 1935-1936," by James R. McConaughie, RG 79, E 411, Box 2493, National Archives and Records Administration. 
staff, as well as the hiring of seasonal employees to act as guides during the busy summer months. McConaughie also recognized that as the "survivors of the Battle" decreased in number, the demand for highly detailed tours based on exact movements of the troops diminished, being replaced by the want for more generalized talks focusing on the site's significance to American history ${ }^{28}$ This new Gettysburg was geared towards planning for posterity by placing the battle's story firmly within the context of a shared American past. In doing so, the new administration's interpretation focused heavily on reconciliation, or the looking past sectional differences in favor of a narrative of heroism, sacrifice, and the emergence of a stronger and more unified nation after the Civil War. ${ }^{29}$

Conversely, the new administration of Fredericksburg and Spotsylvania continued to favor a Lost Cause narrative, giving primacy to the stories of Confederate troops and Southern leaders. Much of the park's interpretation revolved around the figures of Robert E. Lee and Stonewall Jackson, particularly at the two Confederate victories of Fredericksburg and Chancellorsville. Branch Spalding, the most influential early superintendent, was overtly sympathetic to Jackson, and seemed unable to accept that the general made tactical blunders. An excellent example of this was a piece Spalding wrote in 1938 about Jackson's line at Fredericksburg, in which the general left a 600-yard gap allowing for a Union breakthrough. Long accepted as a rather large mistake, Spalding argued that Jackson intentionally did this in order to lead federal troops in to what he referred to as a "deliberate trap." ${ }^{30}$ Land acquisitions undertaken in the 1930s reflected this preoccupation with Confederate leaders as well. The

\footnotetext{
${ }^{28}$ Department of the Interior, National Park Service, "Superintendent's Annual Report for the Year 1935-1936," by James R. McConaughie.

${ }^{29}$ Murray, "'Far Above Our Poor Power to Add or Detract," 70.

${ }^{30}$ Branch Spalding, "Jackson's Fredericksburg Tactics," Spring 1938, 5, No File, Cabinet 7, Drawer 1, FRSP Basement Files, Fredericksburg and Spotsylvania National Military Park Archives.
} 
administration built roads along Confederate battle lines, and a special ceremony on October 23, 1937 commemorated the transfer of the "Stonewall Jackson Shrine," the place where the general died, from the Richmond, Fredericksburg, and Potomac Railroad to the NPS. ${ }^{31}$ This Southernleaning narrative would influence park interpretation for decades, even up until the present day.

By the 1930s, technological advances such as improved road networks and automobile tourism allowed Civil War battlefields to be experienced on a truly national level. ${ }^{32}$ The federal government was also taking an active role in tourism, including enacting legislation to "encourage, promote and develop, by such means as may be necessary, travel within the United States, its territories and possessions." ${ }^{\text {33 }}$ It was also expanding the number of historic sites preserved. The Historic Sites Act of 1935 was monumental legislation, which was written as "a national policy to preserve for public use historic sites, buildings, and objects of national significance for the inspiration and benefit of the people of the United States." ${ }^{34}$ This farreaching legislation would allow numerous historic sites to not only be preserved, but also experienced by generations of Americans.

Marguerite Shaffer thoroughly analyses the rise and shifting meaning of "national tourism" in the early $20^{\text {th }}$ century in her work, See America First: Tourism and National Identity, 1880-1940. The author analyzes tourism in this period as a ritual of American citizenship, and that by learning about their nation through experience people were better able to uncover both

\footnotetext{
31 "Railroad Chief Presents Deed," Free Lance-Star, October 25, 1937. FRSP Lands Files, Fredericksburg and Spotsylvania National Military Park Archives.

${ }^{32}$ Weeks, Gettysburg, 154; Unrau, “Administrative History: Gettysburg National Military Park and National Cemetery, Pennsylvania," 183.

${ }^{33}$ L.C. Speers, "Bill to Aid Tourist," New York Times, February 5, 1939. ProQuest Historical Newspapers: Accessed January 12, 2015.

34 "Historic Sites Act of 1935," August 21, 1935 (49 Stat. 666; 16 U.S.C. 461-467). http://www.cr.nps.gov/local-law/FHPL_histsites.pdf
} 
their personal and national identities. ${ }^{35}$ Furthermore, it was a way to "reconcile this national mythology, which celebrated nature, democracy, and liberty, with the realities of an urbanindustrial nation-state dependent on extraction, consumption, and hierarchy." ${ }^{36}$ The emergence of national parks was a huge component of the success of this type of tourism. Describing the "banner year" national parks had in 1934, an article by National Park Service Director Arno Cammerer from 1935 showed the expectation that the parks' popularity would continue to increase. Claiming that "Americans are on the move to the national parks, for these areas have become a necessity in our economics life to counteract the effects of increased urbanization of our population and to meet the problem of shorter working hours with their resultant leisure," Cammerer illustrated the attractiveness of these national spaces to early $20^{\text {th }}$ century Americans. ${ }^{37}$ More than 15 million tourists visited national parks in 1934, and the expectation was for that figure to increase with every coming year.

Historic parks in particular were vital to forging national identities. One 1936 article eloquently states, "Motor tourists who have a historical bent may find the Epic of America written for them with axe and spade, with trowel and hammer, on a thousand hills and valleys of the continent," and that the National Park Service is the entity responsible for "the vast program for the preservation and rehabilitation of historic sites and monuments now under way. ${ }^{38}$ Another article gave advice as to how to easily visit major historic sites on the 1095-mile journey from New York City to St. Augustine, Florida. Although an individual could reach Florida after

\footnotetext{
${ }^{35}$ Marguerite S. Shaffer, See America First: Tourism and National Identity, 1880-1940

(Washington, D.C.: Smithsonian Institution Press, 2001), 3-5.

${ }^{36}$ Shaffer, See America First, 5.

${ }^{37}$ Arno B. Cammerer, "Parks Look for Big Season," New York Times, April 14, 1935. ProQuest Historical Newspapers: February 20, 2015.

${ }^{38}$ Oliver McKee, Jr., "Highways Unroll Our History,” New York Times, April 19, 1936. ProQuest Historical Newspapers: February 20, 2015.
} 
"twenty-seven hours of continuous driving at the average speed of forty miles an hour," the trip would be more beneficial to the tourist by taking advantages of historical stops along the way. Since every historic site on the eastern seaboard could not be included, the author chose sites under the umbrella of the National Park Service "because of their epoch making character will serve as a nucleus around which to build a motor excursion into antiquity."${ }^{, 39}$ Also significant in this passage is the idea that by entering historic tourist space, the visitor was entering the past. Battlefields were included in this increase in historic tourism in the 1930s, the "shifting preferences in the choice of recreation spots" towards military parks. ${ }^{40}$

The relationship between national tourism and tourists was a dialogue; visitors to national shrines had a profound effect on shaping the spaces. ${ }^{41}$ Not only did the government seek to "popularize the 'See America First' movement," but they also reacted to the needs and desires of the tourists. ${ }^{42}$ The relocation of New Deal funds to the betterment of tourist infrastructure was an excellent example of this symbiotic relationship. Physical improvement projects "financed by WPA allotments totaling $\$ 2,090,500$ ” were primarily “designed to provide greater convenience and comfort for visitors and includes sanitation facilities, water systems and lighting and power plants." ${ }^{, 43}$ The rising popularity of battlefields, and the need for the education of the average visitor at them, yielded similar results. As of 1936, "the Civil War battlefields, especially those in Virginia, have been restored to a point where the student, or the casual visitor, can obtain a

\footnotetext{
${ }^{39}$ Isabelle F. Story, "Southward over the 'Battlefield Trail," New York Times, November 7, 1937. ProQuest Historical Newspapers, February 20, 2015.

${ }^{40}$ Speers, "Bill to Aid Tourist."

${ }^{41}$ Shaffer, See America First, 5.

${ }^{42}$ Speers, "Bill to Aid Tourist."

${ }^{43}$ Ibid.
} 
graphic picture of an eventful period in American history., ${ }^{44}$ Tourists at this time were seen as consumers of culture, and their satisfaction was something the government wished to ensure.

Although commercial innovations and new ideas concerning historic preservation allowed for the $75^{\text {th }}$ Anniversary to occur on a national scale, the fact that it occurred at all hinged on the nation's desire to reconnect with past events such as the Civil War.The Great Depression of the 1930s represented a period of crisis, which had Americans "clinging to their past for reassurance." ${ }^{45}$ The emphasis of commemorative programming in the 1930s was on the heroism of the Civil War past, while still underlining the patriotic sacrifice of the average Civil War soldier. Many politicians and other leaders used this version of the Civil War experience as a lesson for Americans dealing with current economic and social strife, as well as a guide for an uncertain future. The time elapsed between the event and the commemoration, as well as the turbulence of the 1930s, allowed for a virulent strain of nostalgia and romanticism for the $19^{\text {th }}$ century in general to develop. Despite sectional bitterness and bloodshed, many Americans saw it as a simpler, more agrarian time. The nostalgia that initially fueled reconciliation, primarily consisting of Northerners concerned about the decline of small, rural communities, was greatly expounded by the exponential growth of urban areas in the 1920s and the subsequent economic crash of the 1930s. ${ }^{46}$ Tourists to sites like Gettysburg and Fredericksburg were looking for an encounter with the "old time," an authentic experience free of modern reminders. This was particularly true of urban visitors. ${ }^{47}$ However, they were also operating under the assumption that this authentic past was somehow superior to the world in which they were currently living. This nostalgia was of the type characterized by Svetlana Boym as "restorative nostalgia," or that

\footnotetext{
${ }^{44}$ McKee, Jr., "Highways Unroll Our History."

${ }^{45}$ Weeks, Gettysburg, 134.

${ }^{46}$ Linenthal, Sacred Ground, 94.

${ }^{47}$ Weeks, Gettysburg, 154.
} 
which longs for the replication of a past time, deals in absolute truth, and is not recognized as nostalgia but as tradition. ${ }^{48}$ This is the attempt of "total reconstructions of monuments of the past," in an attempt to "rebuild" the mythical "lost home." "It It manifested itself in many different social and cultural ways.

The 1930s narrative of the Civil War was invariably tied with the idea of righteous sacrifice, and this can be seen in no better context than the popularity of visiting battlefields and other Civil War-related sites on Memorial Day. A May 25, 1935 New York Times article noted that, "Much of the travel will converge upon the little town of Gettysburg," not only because it was known as the turning point of the Civil War, but because it was also the "ground that Lincoln consecrated with his immortal address in 1863, five years before May 30 was officially designated for the purpose of strewing with flowers or otherwise decorating the graves of comrades who died in defense of their country. ${ }^{, 50}$ Although not singularly a Civil War site, the Tomb of the Unknown Soldier became a popular symbol for Memorial Day at this time as well. A 1932 article stated that although Americans had their share of "triumphal arches and statues of conquerors on horseback," more and more they were "coming to think of battle in terms of the heroic wreckage typified by the Unknown Soldier, and our great military holiday is not an anniversary of victory but Memorial Day." ${ }^{51}$ This was not an exercise in cynicism or the futility of war, but instead in the "spirit of 'dedication to the great task remaining before us'," an

${ }^{48}$ Svetlana Boym, "Nostalgia and Its Discontents," in The Collective Memory Reader, ed. Jeffery K. Olick, Vered Vinitzky-Seroussi, and Daniel Levy (New York, N.Y: Oxford University Press, 2011), 453-54.

${ }^{49}$ Svetlana Boym, The Future of Nostalgia (New York: Basic Books, 2001), 41-43.

${ }^{50}$ E.L. Yordan, "To the Shrines of the Nation," New York Times, May 26, 1935. ProQuest Historical Newspapers: Accessed February 20, 2015.

${ }^{51}$ K.L. Duffus, “America's New Symbol of Memorial Day,” New York Times, May 29, 1932. ProQuest Historical Newspapers: Accessed February 20, 2015. 
affirmation that the sacrifice of the nation's war dead was not in vain. ${ }^{52}$ The sacrifice of Civil War soldiers was in order to unite the nation, forging the bonds stronger than ever. This belief was reflected in President Roosevelt's Memorial Day address at Gettysburg in 1934, where he condemned sectionalism, stating that "in the presence of the spirits of those who fell on this ground, we give renewed assurance that the passions of war are moldering in the tombs of time and the purposes of peace are flowing in the hearts of a united people. ${ }^{.53}$ That the nation could be "all brothers now in a new understanding," was because of the sacrifices of nearly seventyfive years prior. ${ }^{54}$ At a time of great economic and social turmoil, the president understood the value of reminding the nation of this sacrificial lesson.

Although Americans placed a primacy on sacrifice in the 1930s, their understanding of the Civil War was not without glory, and through this avenue sectionalism often emerged. This can be seen in the admiration of popular historians such as Douglas Southall Freeman. A native Virginian and the editor of the Richmond News Leader, he was the son of a private in Robert E. Lee's Army of Northern Virginia. According to Keith Dean Dickson's work on Freeman's role in advancing collective Southern memory, "Freeman not only embraced the ideals and myths of the Confederate generation, he did a great deal to validate and perpetuate them. ${ }^{, 55}$ Best known for his biographies of Robert E. Lee and George Washington, as well as his compilation biography of Confederate generals, Lee's Lieutenants, the prolific and dynamic Freeman enjoyed an immense popularity in the early $20^{\text {th }}$ century. His biography R.E. Lee won him his first Pulitzer Prize in 1934, and his readership had reached mainstream Americans enough to have his

\footnotetext{
52 Ibid.

53 “50,000 Hear President," New York Times, May 31, 1934. ProQuest Historical Newspapers: Accessed February 20, 2015.

${ }^{54}$ Ibid.

${ }^{55}$ Keith Dean Dickson, "The Divided Mind of Douglas Southall Freeman and the Transmission of Southern Memory" (PhD diss.: University of Virginia, 1998), 5.
} 
books heavily featured on the New York Times' Christmas book list suggestions. ${ }^{56}$ Viewing himself as a protector of southern memory and tradition, Freeman's works emphasized Confederate military leaders such as Lee and Stonewall Jackson over common soldiers, applying to them a mythic and heroic status. Personally, he also aggressively supported paternalism and the strengthening of Virginia's segregation laws ${ }^{57}$ Freeman had an acquaintanceship with Fredericksburg and Spotsylvania superintendent Branch Spalding, and donated his time to speak at multiple park programs. ${ }^{58}$ Although there is no definitive way to measure Freeman's influence on the interpretation at the southern battlefield park, it was without question profound.

Finally, romanticization of the agrarian past was certainly alive and well. For example, the extremely popular 1939 film Gone with the Wind, based on the novel by Margaret Mitchell, heavily sentimentalized both the Southern cause and the plantation past. ${ }^{59}$ An article following the release of the film hinted at the cultural phenomenon's effect on a new generation of Georgians, stating that since only six Confederate veterans remain in the state of Georgia's veterans home, the "old soldiers" are no longer able to "rally to annual reunions and tell of the glories and braveries of the Lost Cause. ${ }^{, 60}$ Instead, it was up to films like Gone with the Wind to give the "new generation, thrice removed from civil strife, a romantic interest and a sentimental feeling for the Confederacy which it had been unable to obtain from its school books or from the tongues of the actors in it, most of whom had died long ago.” The film was said to inspire a small

\footnotetext{
56 "Books-Authors," New York Times, September 4, 1942. ProQuest Historical Newspapers: Accessed March 3, 2015; "A Wide Choice for Readers in the Christmas Book Lists," New York Times, December 2, 1934. Proquest Historical Newspapers: Accessed March 3, 2015.

${ }^{57}$ Zenzen, 98.

${ }^{58}$ Ibid.

${ }^{59}$ Brian Steel Wills, Gone with the Glory: The Civil War in Cinema (Lanham, Md: Rowman \& Littlefield : Distributed by National Book Network, 2007), 29-32.

${ }^{60}$ Edwin Camp, "'Gone with Wind' Stirs the South," New York Times, December 17, 1939. ProQuest Historical Newspapers: Accessed February 5, 2015.
} 
ceremony in downtown Atlanta, the relighting of a gas lamp, which was hit by a shell during Sherman's siege of the city in 1864 . Although seemingly unremarkable, the pageantry surrounding the relighting included a band playing the notes of "Dixie," and a dedicatory speech referring to the lamp as the "eternal flame of the confederacy." 61 Although the subheading of the article claimed that these exercises were "pride," not "sectionalism," it is clear that this was an instance of the reemergence of a sentimental and romanticized strain of the Lost Cause.

Nostalgia for the past as a whole was also strongly present in physical changes made to the battlefields during the decade. Superintendent James McConaughie of Gettysburg explained this manifestation of restorative nostalgia by stating "the primary purpose is to preserve an area of great historical value in such a manner as to permit the visitor to visualize conditions of the day," and that "the word, "Park' and the date, "1863" are two definite guiding factors placed in front of the developer and administrator today." Although he accepted that certain encroachments of modernity were inevitable, he also stated that they must not be "too obvious." ${ }^{62}$ This attempt to recreate 1863 for modern visitors differs greatly from the commemorative efforts practiced by Civil War veterans, and resulted in a massive overhaul of these battlefields' commemorative landscapes. These physical transformations will be explored in the next chapter.

The administrative transfer of both the battlefields at Gettysburg and Fredericksburg and Spotsylvania in the 1930 s occurred at a time dramatically poised for change. Economic and cultural turmoil related to the Great Depression, nostalgia for a more agrarian and romanticized $19^{\text {th }}$ century past, and increased emphasis on the value of historic cultural heritage tourism all

\footnotetext{
${ }^{61}$ Camp, "'Gone with Wind' Stirs the South."

${ }^{62}$ Branch of Historic Sites, Gettysburg National Military Park Master Plan, 1939, September 2, 1939, GNMP Library.
} 
contributed to the ascension of battlefield spaces as attractive destinations for the American public. Both the tourist's expectations for these spaces and the dynamic figures of the new National Park Service administrators, both at the federal and park level, influenced a shifting purpose in these commemorative spaces. No longer were Civil War battlefields primarily spaces for veteran reunions and commemorative efforts. They were now spaces for all Americans, or at least those with the means and opportunity, to not only learn about, but also immerse themselves, in the past. 
Chapter 2: “The Work Has Only Begun:” Transforming a Commemorative Landscape

In the early summer of 1938, Dr. Louis E. King assessed the work already completed by a group of young men living in orderly, landscaped barracks off of Gettysburg's Confederate Avenue. Having received his $\mathrm{PhD}$ from Columbia University, King was by no means a typical enrollee of the Civilian Conservation Corps. In fact, he was entirely unique as the only African American historian on active duty with the National Park Service. For two years, along with other African American leaders, he was in charge of organizing the labor of over two hundred young men at a time. Their goal was to transform the landscape of the Gettysburg battlefield through repair, improvement, and restoration. In addition to allowing for everyday visitors to gain a sense of the battlefield's historic condition, these physical alterations were also undertaken by the new National Park Service administration in an effort to ready Gettysburg for the commemorative exercises planned for the $75^{\text {th }}$ anniversary of the battle.

Although the Great Depression of the 1930s was initially an obstacle to the expansion of the National Park Service, the New Deal programs enacted by President Franklin D. Roosevelt eventually provided the manpower to make these ideological and physical transformations possible. Many New Deal programs were conservation oriented, as much of the nation at least partially blamed the misuse and waste of national resources for the dire economic plight. ${ }^{1}$ Therefore, the Park Service, now including its historical parks, benefitted from this program immensely. ${ }^{2}$ Not only were out of work historians employed by New Deal programs in vast numbers, but the labor provided by the Civilian Conservation Corps (CCC) was integral to the

\footnotetext{
${ }^{1}$ Neil M. Maher, Nature's New Deal: The Civilian Conservation Corps and the Roots of the American Environmental Movement (New York: Oxford University Press, 2008), 6.

${ }^{2}$ Everhart, The National Park Service, 58.
} 
Park Service's emerging battlefield rehabilitation. Ralph Happel, later Superintendent of Fredericksburg and Spotsylvania National Military Park, was initially employed as a CCC historian, whose primary job was to "write up a justification for everything the CCC boys were doing." ${ }^{3}$ His explanations showed less about how the CCC's work fit into the new park's mission of education and battlefield rehabilitation than illustrating the complicated nature of New Deal relief efforts within the Park Service. As the goal of these programs was to put unemployed young men back to work, the reasoning for the work itself was often of secondary importance.

Much of the labor necessary for battlefield transformation was conducted by the Civilian Conservation Corps. One of the most successful New Deal programs, the CCC was also one of the most popular with the nation. Described in a 1937 publication as "the greatest single achievement" of the Roosevelt Administration and the "beginning of an unique renaissance of American life," the CCC was almost instantly romanticized. ${ }^{4}$ Typically associated with the transformation of vast expanses of the America's natural environment, the folkloric "mystique of the forest", and the "human conservation" of young urban boys into healthy, hard-working men, the CCC's effect on smaller, historical National Parks is often overlooked. ${ }^{5}$ Despite the smaller scale, the environmental transformation brought to Civil War battlefields was just as dramatic and far-reaching as those in the great Western forests.

Both Gettysburg and Fredericksburg and Spotsylvania benefitted from CCC labor for much of the decade. Two Civilian Conservation Corps camps, Camp No. 1 and Camp No. 2,

${ }^{3}$ Interview with Ralph Happel by A. Wilson Greene. 1978. Typescript. BV 545. Fredericksburg and Spotsylvania National Military Park Archives.

${ }^{4}$ Alfred C. Oliver, Jr., and Harold M. Dudley. This New America: The Spirit of the Civilian Conservation Corps (New York: Longmans, Green and Co., 1937), xiii.

${ }^{5}$ For more on landscape transformation and human conservation brought about by the CCC, see Maher's Nature's New Deal. For more on the popularity of the CCC, see John A. Salmond's The Civilian Conservation Corps, 1933-1942: A New Deal Case Study (Durham, NC: Duke University Press, 1967). 
were established at Gettysburg in 1933. Camp No. 1 was abandoned in 1937, but Camp No. 2 continued to operate until 1942, when World War II undercut the necessity for the Corps. ${ }^{6}$ Their work not only included manual labor and battlefield rehabilitation, but also historical research and even the selection of certain enrollees to act as junior historians and park guides. Three camps were established at Fredericksburg and Spotsylvania, one on the Spotsylvania, Chancellorsville, and Wilderness battlefields, MP-1, MP-3, and MP-4 respectively. About two hundred men called each of these camps home at a time, and the camps existed from the establishment of the Spotsylvania camp in 1933 to their eventual discontinuation in 1942. After receiving \$1 million of federal emergency relief money and hundreds of laborers, the park ended this pivotal decade with a new administration and museum building, twenty-one miles of roads, contact stations at each battlefield, massive battlefield rehabilitation efforts, and 100,000 new trees. ${ }^{7}$ Just as significant as the administrative shift underwent by military parks in the 1930s were these transformation of the physical landscape.

The changes to the battlefields had two purposes: to provide visitors with ease of access and to restore these battlefields to what was perceived as their wartime appearance. These attempts to rehabilitate the land "to the condition as found during the world famous battle fought over its grounds," at times directly conflicted with the landscape of commemoration created by the veterans. The NPS administration and the various CCC camps also had to navigate contact

\footnotetext{
${ }^{6}$ Unrau, 160-61.

${ }^{7}$ Zenzen, 59.
} 
with the local communities, which could quickly become problematic. Although some members of the CCC were local, many were from different regions, which could breed resentment and the general treatment of the enrollees as outsiders. Race was also a huge factor in tensions with local entities, as many of the parks contained at least one African American CCC camp. Like any major change, the physical transformation of the battlefield landscape was not without conflict. One of the most long-lasting projects of the CCC and the National Park Service was the development of roads throughout the battlefields. Before the National Park Service, many roads to battlefield areas were dangerous, unmarked, or completely nonexistent. A newspaper article from 1926 illustrated the problematic and frustrating nature of visiting the battlefields in the Fredericksburg area. A disgruntled visitor explained that Fredericksburg was the only battlefield that could be visited with ease due to its proximity to the city. He also "got stuck in the mud twice," attempting to visit the site of Robert E. Lee and Stonewall Jackson's last meeting, which was only about a mile from a main road. Finally, he concluded that many areas of the battlefield were "impossible for anyone to do without a most experienced guide." ${ }^{.8}$ Although another article from two years later more optimistically explained that, "surprised tourists today find that the high spots of the battlefields may be reached by good roads," it admitted "the work has only begun." " Just one decade brought dramatic changes; maps published by the Park Service in the early 1940s show road networks reaching the areas of significant action on all four of the battlefields within Fredericksburg and Spotsylvania National Military Park. ${ }^{10}$ At Gettysburg, the

\footnotetext{
8 "Neglected V.A. Battlefields Hard to Reach By Motor." Fayette Tribune, December 29, 1926. BV 191. Fredericksburg and Spotsylvania National Military Park.

9 “A Virginia Battle Zone Wins Late Recognition," New York Times, August 30, 1931. ProQuest Historical Newspapers, Accessed January 17, 2015.

${ }^{10}$ 1940s Map of the park, FRSP_326_2112.pdf, in Joan M. Zenzen, At the Crossroads of Preservation and Development: A History of Fredericksburg and Spotsylvania National Military Park. Administrative History. August 2011.
} 
period between 1933 and 1939 also marked a "very distinct improvement" in safety and convenience of park roads. ${ }^{11}$ Members of the $\mathrm{CCC}$ also made roads more aesthetically pleasing by cleaning up debris along existing thoroughfares so that visitors could more easily see the trenches, as well as planting trees along the new park roads. ${ }^{12}$

Superficially roads may seem like a fairly innocuous structural change, but this process was not without conflict. At Gettysburg, two of the park's avenues, intended by veterans to follow the lines of battle, were relocated on the account that they contained sudden and dangerous curves. ${ }^{13}$ The work on Slocum Avenue and Sykes Avenue, undertaken by the Bureau of Public Roads using Public Works Administration funds, was completed despite objections from park historians. Not only did they reiterate the objection that the roads were meant to follow the lines of battle, but they also complained that the new path of the roads would "mar heretofore undisturbed terrain over which troops passed into battle," therefore disrupting the natural landscape. ${ }^{14}$ Although this change has a practical reason, it represents a shift from a landscape built for veterans wishing to tour the exact lines of their former army to mass tourism valuing safety and convenience. It further illustrated that the desires for education and convenience were not always harmonious.

\footnotetext{
${ }^{11}$ U.S. Department of the Interior, National Park Service, Gettysburg National Military Park, “Superintendent's Preliminary Annual Report for Fiscal Year 1939," pp. 14-16, File No. 207-01, Gettysburg, CCF, RG 79. Gettysburg National Military Park Archives.

${ }^{12}$ Interview with William Howard by A. Wilson Greene. 1978. Typescript. BV 545. Fredericksburg \& Spotsylvania National Military Park Archives.

${ }^{13}$ Weeks, Gettysburg, 120; Unrau, 161.

${ }^{14}$ U.S. Department of the Interior, National Park Service, Gettysburg National Militayr Park, "Superintendent's Annual Report for Year 1935-1936, James R. McConaghie, Superintendent, pp. 23-24, File No. 207-01, Gettysburg, CCF, RG 79, R.L. Jones to Chatelain, June 20, 1934, and Allison to Chatelain, June 18, 1934, Vertical Files, Roads, Avenues, and Rights-of-Way, Folder 3, GNMP Library
} 
Another dramatic change from the War Department days was the emergence of numerous visitor contact stations. These contact stations were built at the locations of many of the major sites of action at Fredericksburg, and CCC enrollees were given the role of staffing them. William Howard, the superintendent of the CCC camp at Spotsylvania, explained in an oral history interview that many of the enrollees who staffed these stations were veterans of the First World War. ${ }^{15}$ The contact stations themselves were designed to fit into the rustic landscape. Small, unimposing wooden cabins with simple furniture, a stone fireplace, and displayed artifacts gave these cabins a mid-nineteenth century feel for the benefit of the visitors. ${ }^{16}$ This type of architecture, referred to as National Park Service rustic, or "Parkitecture," is "a style which, through the use of native materials in proper scale, and through the avoidance of rigid, straight lines, and oversophistication, gives the feeling of having been executed by pioneer craftsmen with limited hand tools." Parks were using Parkitecture prior to the Great Depression, but it was mainstreamed and introduced to historic sites in the 1930s. ${ }^{17}$ Although this style fell out of use after World War II, structures built to achieve "sympathy with natural surroundings and with the past" remain on battlefields today. ${ }^{18}$ Even the larger brick Colonial Revival structure that served as the Park's main museum, today the Fredericksburg Visitor Center, was designed to appear as if it could have stood during the battle. This was particularly important

\footnotetext{
${ }^{15}$ Interview with William Howard by A. Wilson Greene. 1978. Typescript. BV 545. Fredericksburg \& Spotsylvania National Military Park Archives.

${ }^{16}$ Photo, Wilderness Box 1, File Wilderness Contact Station, FRSP Photo Archives; Photo, Spotsylvania Box 1, File Spotsylvania Contact Station Bloody Angle, FRSP Photo Archives. ${ }^{17}$ Laura S. Harrison, Architecture in the Parks: A National Historic Landmark Theme Study, (National Park Service, Department of the Interior, 1986), 7-8; Quote from Albert Good, Park and Recreation Structures, Part !: Administration and Basic Service Facilities (United States, Department of the Interior, National Park Service, 1938), 9. https://archive.org/details/parkrecreationst00good.

${ }^{18}$ Good, Park and Recreation Structures, 9.
} 
because of its location directly adjacent to the Sunken Road. ${ }^{19}$ These designs often sacrificed some aspects of functionality for the ability to blend into the built landscape.

At Gettysburg, CCC enrollees also spent a considerable amount of time constructing parking areas and footpaths to accompany the new park roads. They also rebuilt historic trails, often abandoned for years, to allow visitors to have safer and easier access to areas of the battlefield away from the paved avenues. ${ }^{20}$ Furthermore, the park undertook massive agricultural developments to rehabilitate "open lands from wasteful use." This included "erosion control projects, landscaping, planting, nursery work," as well as the elimination of plants known to be hosts of pests as well as those not native to the area. ${ }^{21}$ As the $75^{\text {th }}$ Anniversary commemorations approached, enrollees also completed temporary infrastructural developments, such as extra drinking fountains, comfort stations, parking areas, and fences to protect new planting. ${ }^{22}$

The parks also released informative guidebooks for tourists to use both in preparation for and during their visits. Before the administrative shift at Gettysburg, only one booklet was available for distribution, and it contained detailed information on monuments, markers, and troop movements not geared toward the average visitor. ${ }^{23}$ The new guidebook for Fredericksburg and Spotsylvania gave a basic overview of each battle, in addition to maps, which is clearly intended for use by an individual with little to no background knowledge of the battle or area. It

\footnotetext{
${ }^{19}$ Photo, Fredericksburg Box 4, File Fredericksburg Visitor Center, FRSP Photo Archives.

20 "Gettysburg CCC Co. Gets Park Ready for Celebration," New Journal and Guide, July 2, 1938. PAIS International: Accessed December 4, 2014.

${ }^{21}$ Ibid.

${ }^{22}$ Ibid.

${ }^{23}$ U.S. Department of the Interior, National Park Service, "Annual Report for the Gettysburg National Military Park, Year Ending September 30, 1934, James R. McConaghie, Superintendent, pp. 2-8, File No. 207.01, Gettsyburg, CCF, RG 79. Gettysburg National Military Park Archives.
} 
also contained a section that lists visitor services provided by the park. ${ }^{24}$ In addition to individual park's guidebooks, the text "Manassas to Appomattox: National Battlefield Park Tour in Virginia," showed that although these parks were operating as independent entities, they were part of a larger effort to promote battlefield tourism nationally. ${ }^{25}$ These books also contained the seals for both the National Park Service and the Civilian Conservation Corps, indicating that both organizations had an equal hand in developing battlefield tourism.

Restoring fencing and stone walls to their pre-battle appearance was another extensive project undertaken in the 1930s. Because "modern types of fencing had been permitted on the battlefield, destroying the appearance and feeling of historic restoration," the two CCC camps at Gettysburg tore down five miles of modern fencing to replace it with fencing similar to the Civil War period, as well as reconstructing twenty-five miles of stone walls and other fortifications. ${ }^{26}$ One of the most visible examples of this was the reconstruction of a portion of the famed stone wall along the Sunken Road on the Fredericksburg battlefield. The stone wall the CCC built was actually less orderly and more distressed than the one which was there in 1862, giving it a far more rustic and worn appearance. This demonstrated that the main concern of the administration was to give the appearance of the past, and not necessarily conducting the archeological and archival research needed to determine how that past actually appeared. ${ }^{27}$ Furthermore, they did not always take into consideration the reaction of veterans and their descendant groups. For example, the reconstruction of the stone wall at the site of the famed Pickett's Charge at

\footnotetext{
24 "Fredericksburg and Spotsylvania County National Military Park Virginia," United States Department of the Interior, 1942.

25 "Manasses to Appomattox: National Battlefield Park Tour in Virginia." United States Department of the Interior, 1940. VF 123. Fredericksburg and Spotsylvania National Military Park Archive.

26 "Gettysburg CCC Co. Gets Park Ready for Celebration."

${ }^{27}$ Photo, Fredericksburg Box 4, File Fredericksburg Visitor Center, FRSP Photo Archives.
} 
Gettysburg induced the ire of veterans and their descendants, which Southerner heritage groups argued was "washed in the blood of their forefathers.",28

Other battlefield preservation efforts undertaken by CCC enrollees included the rehabilitation of historic structures and the cleaning and resetting of gravestones in national cemeteries. At Gettysburg, for example, the two CCC companies restored both the small house that served as Meade's headquarters as well as the house where Lincoln was said to have prepared the Gettysburg address. Furthermore, the "entire area has been reconstructed by these workers in Uncle Sam's peacetime conservation army to preserve the historical continuity., 29 Referred to as one of "the most outstanding projects which have been completed by" the CCC enrollees was the resetting of the headstones in the national cemetery, readying the area for memorial exercises. ${ }^{30}$

The CCC also built up earthworks, or trenches, built by Civil War soldiers, as time and erosion had caused the earthworks to be worn down until they were gentle earthen mounds. They either added height to the earthworks to make them more prominent, or in some cases even built an example of what the earthworks would have looked like in the 1860s directly over the existing landform. ${ }^{31}$ One of the first examples of this was at the scene of the Bloody Angle, on the Spotsylvania Court House Battlefield. A 1936 newspaper article described the "reconstruction work undertaken by the National Park Service," highlighting that the "rebuilding of a section of

\footnotetext{
${ }^{28}$ John C. Paige and United States, The Civilian Conservation Corps and the National Park Service, 1933-1942: An Administrative History (Washington, D.C.?: National Park Service, U.S. Dept. of the Interior, 1985), 114; Weeks, Gettysburg, 120-21.

29 "Commemorative Exercises Are Held at Gettysburg," The Pittsburgh Courier, November 18,1936. ProQuest Historical Newspapers: Accessed January 12, 2015. 30 "Youths Learn Really How to Live in C.C.C.," New Journal and Guide, June 26, 1937. ProQuest Historical Newspapers: Accessed January 12, 2015.

${ }^{31}$ Wilderness Box 1, File Wilderness Trenches, FRSP Photo Archives; Spotsylvania Box 3, File Spotsylvania Trench Restoration, FRSP Photo Archives, 1935.
} 
one of the Confederate trenches has already started." 32 As the term "rebuilding" implies, the CCC created examples of how it was believed earthworks appeared in 1864 over top of the existing mounds, thus obliterating natural erosion as well as compromising archeological evidence. Evidence of this decision can still be seen at the Bloody Angle today, with the CCCbuilt earthworks now falling into disrepair. The fortification of earthworks, something modern preservationists discourage, was not without controversy in the 1930s.

One pivotal example of this disregard for the veterans' built landscape was the use of trees and natural features to conceal monuments and markers from visitors. Over time, the words "Civilian Conservation Corps" and "trees" have become practically synonymous. Between 1933 and 1942, members of the CCC planted two billion trees. ${ }^{33}$ Where the CCC went, trees followed, and Civil War battlefields were no exception. The enrollees removed some trees, such as the nine hundred acres of woodland at Gettysburg which "had been allowed to grow at will for about twenty years with a resultant overgrowth of underbrush which created a fire hazard, seriously affected desirable secondary growth, and closed the area to foot travel." 34 However, planting efforts at these parks were far more deliberate then mere reforestation. There were both practical and aesthetic reasons for tree planting. In some cases, trees were planted to prevent soil erosion, despite the effect on the historic view shed. ${ }^{35}$ In other instances, the purpose of the trees was merely to make roadways appear more natural and attractive, such as along Lee Drive on the Fredericksburg battlefield. ${ }^{36}$ Although vista cutting projects were conducted when post-war

\footnotetext{
32 “'Bloody Angle' Trenches at Spotsylvania Rebuilt," The New York Times, May 3, 1936. ProQuest Historical Newspapers: Accessed December 1, 2014.

${ }^{33}$ Maher, Nature's New Deal, 3.

34 "Gettysburg CCC Co. Gets Park Ready for Celebration."

35 Paige, The Civilian Conservation Corps and the National Park Service, 1933-1942, 114.

${ }^{36}$ FRSP Annual Report, Fiscal Year 1938, 4, File 207 Reports, Box 2468, RG 79, NARAArchives II.
} 
growth challenged visitor understanding of the battlefield, such as the slopes of Gettysburg's Little Round Top, trees themselves were seen as acceptable modern encroachments. A 1937 NPS Restoration Policy listing post-war additions to the battlefield described the "forest growth of 75 years frequently is a desirable witness to the age and the dignity of a battlefield area and fortifies the impression upon those visiting the area." ${ }^{, 37}$ This showed that although these trees are not from the 1860s, they were acceptable for this new battlefield landscape because they fit the rustic landscape the NPS was hoping to create for visitors. However, one aspect of the existing landscape which did not fit with this vision were the numerous monuments and markers erected by veterans.

At Gettysburg, the CCC also planted trees and shrubs in order to screen the numerous monuments from view. ${ }^{38}$ This revealed that the veterans' built landscape did not fit with the image of the past advanced by the 1930s Park Service. To veterans and early commemorative groups, the erection of monuments was key to the battlefield landscape, which they believed was primarily a space for reunions and honoring their fallen comrades. A pamphlet published by the Gettysburg Battlefield Memorial Association in 1885 cited "one of the main aims of the Association is to facilitate the erection of Memorial Tablets and Monuments." ${ }^{39}$ A publication on the monuments a few years later described the hope that future generations would be presented with "works of art to perpetuate... the position of every one of the three hundred and sixty regiments and batteries of the Union army that participated in the battle," as well as attempts by

${ }^{37}$ Frederick Tilberg to Regional Director, Region One, October 3, November 4, and December 3, 1940, File No. 207, Gettysburg, CCF, RG 79; NPS Restoration Policies, May 19, 1937. Gettysburg National Military Park Archives.

${ }^{38}$ Weeks, Gettysburg, 120.

${ }^{39}$ Gettysburg Battlefield Memorial Association: Its Organization, Plans and Purposes ([Gettysburg, 1885]), n.p. Gettysburg National Military Park Library. 
Confederate veterans to mark the field. ${ }^{40}$ Once seen as a programmatic imperative by groups largely influenced by veterans, the same monuments, in the eyes of early Park Service officials, were unappealing and disruptive to the visitor experience. Superintendent James McConaghie was highly vocal on his opinions concerning Gettysburg's vast monumentation, referring to the monuments as "questionable" and the field as marked "almost to the cemetery - or graveyard condition. ${ }^{, 41} \mathrm{He}$ also expressed concerns with the aesthetic value of the monuments, explaining in the Park's 1939 Master Plan that "an emotional stage caused the erection of monument after monument with the interest primarily in the purpose of the structure rather than in the structure itself." In a new age where visitors lack a "direct touch" to the battle, "the structure itself is primary" and the "result is not so favorable." His solution to this visual conundrum was to "carefully plant so that the numerous monuments will appear to fit and be screened so as not to unduly affect the landscape. ${ }^{, 42}$ The disregard for the veterans' built landscape clearly indicates the vast differences in these competing visions for the commemorative environment.

Although the primary purpose of Civil War battlefields was to educate, a strong secondary component of the Parks' missions at this time was to provide recreational opportunities for visitors, particularly for those travelling from urban areas. The addition of recreational components to the parks derived from the thinking of landscape architect Frederick Law Olmstead, who believed that nature had a rejuvenating effect on city-dwellers. Although Olmstead used this for justification for city parks, increased automobile tourism allowed it to be

\footnotetext{
${ }^{40}$ J. Howard Wert, A Complete Hand-Book of the Monuments and Indications And Guide to the Positions on the Gettysburg Battle-Yield, 5.

${ }^{41}$ Memorandum of the Proposed Transfer of Military Parks and Monuments for the Use of the Director in Connection with the Superintendents' Conference as Required by His Memorandum of March 5, 1932, Old History Division Files, WASO.

${ }^{42}$ Branch of Historic Sites, Gettysburg National Military Park Master Plan, 1939, September 2, 1939, GNMP Library.
} 
applied to rural areas during the Great Depression. ${ }^{43}$ The National Park Service adopted this view, as illustrated by former director Stephen Mather's description of the parks as "great out-ofdoors recreation grounds, where men, women and children can forget the cares and the sounds of the cities for a few days. ${ }^{, 44}$ One particularly poignant example of this was Fredericksburg and Spotsylvania's effort to create a two-acre wildflower preserve on the Chancellorsville battlefield, complete with a foot trail leading along Civil War trenches ${ }^{45}$. Advertised heavily in a May 20, 1935 leaflet, the park stated that its educational opportunities were by no means "confined" to historical education, and that the Jackson Memorial Wild Flower Preserve presented an “important recreational and educational" opportunity affording "excellent instruction in botany," which was a "delight to lovers of the outdoors." ${ }^{\text {"46 }}$ This preserve partially obscured, or at least took emphasis away from, two monuments placed by Confederate veterans to Stonewall Jackson's wounding. In an article concerning the dedication of the larger Jackson monument in 1887 , the purpose of monuments was described as to "preserve history, educate the young, perpetuate the memories of the heroic dead, and help to keep alive the virtue and valor of those whose names they bear. ${ }^{, 47}$ 1930s superintendent Branch Spalding described the Wildflower Preserve with shockingly similar language, stating that the flowers were "silent witness" to the "unintentional blow which felled a mighty warrior." He went as far as to assert that the flowers

\footnotetext{
${ }^{43}$ Maher, 8.

${ }^{44}$ Stephen T. Mather was the first director of the National Park Service (1917-1929), and wrote these words for the second edition of "Oh, Ranger, " Horace Albright and Frank Taylor's treatise on the National Park Service. Horace M. Albright and Frank J. Taylor, "Oh, Ranger!" A Book about the National Parks, Revised Adddition (New York: Dodd, Mead \& Company, 1947), x. ${ }^{45}$ Photo, Chancellorsville Box 4, File Chancellorsville Wildflower Preserve, FRSP Photo Archives.

46 "Jackson Memorial Wild Flower Preserve." Fredericksburg and Spotsylvania National Military Park. May 20, 1938. VF 123. Fredericksburg and Spotsylvania National Military Park.

47 "Monument to Stonewall Jackson." Winchester Times. March 2, 1887. BV 492. Fredericksburg and Spotsylvania National Military Park Archives.
} 
may even be considered a more fitting memorial, as they were "to the taste of the simple and devout figure" that was Jackson. ${ }^{48}$ However, the 175 varieties of flowers deliberately placed to evoke a naturalistic setting were clearly geared towards recreational enjoyment, and did little to evoke memorialization of Jackson aside from the preserve's name. ${ }^{49}$ Much of the solemnity and ceremony of the monument was usurped by a recreational space focusing on natural beauty and relaxation, illustrating that enjoyment and ambiance was a vital component of this new landscape.

Both the National Park Service and the CCC had a profound effect on local communities. Perhaps the most significant of these changes was the physical transformation of these communities through land acquisitions and relocation. Many people were asked, or even forced, to move from property that had been with their family for generations. An interview with Mrs. Hallie Rowley Sale, a Spotyslvania County resident, describes her family experience living near the Chancellorsville battlefield:

My grandmother and grandfather lived in the old house there and when I was born I lived in the Chancellorsville house. And, of course, when after awhile my grandfather built what we called Libby House - you know, up there by Bullock Road - you know the house, the little house. Of course the Governement bought it and tore it down...

She then proceeded to detail other property purchased at this time, which indicated that her experience was not uncommon. In Gettysburg, much of the tension with the community derived from the Park Service's attempts to inhibit development in areas adjacent to the battlefield. For example, in 1940 the growth of tourism sparked the possible "development of a dance pavilion,

\footnotetext{
${ }^{48}$ Branch Spalding, "Flowers to Jackson's Memory," September 1935, copied from The Commonwealth, NO File, Cabinet 7, Drawer 1, FRSP Basement Files. Fredericksburg and Spotsylvania National Military Park Archives.

${ }^{50}$ Interview with Mrs. Hallie Rowley Sale by Donald Pfanz, March 5, 2004. Typescript. BV 546. Fredericksburg and Spotsylvania National Military Park Archives.
} 
swimming pool, souvenir and refreshment stand, and a cabin group" which threatened "to impair seriously a section of the battlefield that up to the present has been unspoiled. ${ }^{, 51}$ Although these changes were to occur on private property, the NPS still took extensive steps to stop any modifications threatening to the idyllic pastoral landscape. Increased tourism to the area brought about tensions with local business owners hoping to capitalize on the park's success.

Locals in Fredericksburg and Spotsylvania County initially opposed the transfer of park land to the National Park Service. They feared the transformations the new administrators wished to make, and wanted to ensure that the land remained "a vast memorial, sacred in its nature" where 100,000 men had fallen, and not a place catering to tourists seeking recreational opportunities. ${ }^{52}$ The park's first superintendent, George Palmer, also faced criticism, largely because he was a Northerner. Eventually, Virginian Branch Spalding replaced Palmer as superintendent, and local relations improved. However, in order to facilitate this improvement, Spalding began aligning the park's interpretation with a Southern leaning Lost Cause narrative, which would continue to influence educational programming for decades, as well as adopting the segregated facilities. ${ }^{53}$ For example, the Fredericksburg museum and administration building had clearly marked separate restrooms for African Americans, located in an entirely different structure. ${ }^{54}$ Land acquisitions and infrastructural improvements largely focused on sites of significant Confederate action, such as the purchase of the Stonewall Jackson Shrine, the site of

\footnotetext{
${ }^{51}$ Johnston to Superintendent, Gettsyburg National Military Park, July 15, 1940, File No. 207, Gettysburg, CCF, RG 79. Gettysburg National Military Park Archives.

52 "Keep the Park As It Is," Free Lance-Star, June 8, 1933.

${ }^{53}$ Zenzen, 63-65.

${ }^{54}$ Photo, Fredericksburg Box 4, File Fredericksburg Visitor Center Garage, FRSP Photo Archives.
} 
Stonewall Jackson's death, from the Richmond, Fredericksburg, and Potomac Railroad. ${ }^{55}$ These concessions appeased local leaders, but also advanced the primacy of a Southern narrative.

The influx of hundreds of young men into CCC camps also had an understandably dramatic effect on small rural communities, and in varying ways. McConaghie's annual report from 1934-35 gave an image of cooperation between the camps and the town, stating that "the camps have fitted nicely into the community," and when "the CCC leaves this community it will leave not only a work well done, but a warm feeling not only toward the work done, but toward this whole emergency movement as well." ${ }^{, 56}$ He characterized conflict as "minor," but also qualified this by stating, "both camps are within walking distance of the center of town." Later reports mention several instances of a CCC enrollee being arrested, including one incident when a fight between two enrollees resulted in one participant's murder. ${ }^{57}$ These occurrences are described in very minimal detail, perhaps in order to downplay any existing tension. In some instances, illegal trades developed between the enrollees and the locals. For example, a 60 -yearold Spotsylvania Country resident named Phenie Tapp was arrested "on complaint of authorities that she was selling liquor to members of the Civilian Conservation Corps camps," fined fifty dollars, and given a thirty day suspended sentence.$^{58} \mathrm{~A}$ couple was also arrested at Gettysburg

\footnotetext{
55 "Railroad Chief Presents Deed," Free Lance-Star, October 25, 1937.

${ }^{56}$ U.S. Department of the Interior, National Park Service, Gettysburg National Military Park, “Superintendent's Annual Report for Year 1934-1935," July 27, 1935, James R. McConaghie, Superintendent, pp. 25-29, File No. 207-01, Gettysburg, CCF, RG 79. Gettysburg National Military Park Archives.

${ }^{57}$ U.S. Department of the Interior, National Park Service, Gettysburg National Military Park, "Superintendent's Annual Report for Year 1936-1937," James R. McConaghie, Superintendent, pp. 7-11, File No. 207-01, Gettysburg, CCF, RG 79. Gettysburg National Military Park Archives.

58 "Woman Fined for Selling Liquor." The Free-Lance Star. BV 492. Fredericksburg and Spotsylvania National Military Park Archives.
} 
for "pandering" near the camps. ${ }^{59}$ This illustrated not only interaction with locals, but also the controlled nature of the CCC camps and ways enrollees found to circumvent these restrictions.

Racial tensions also contributed to community relations with the CCC. Out of 2.5 million CCC enrollees only 200,000 to 300,000 were African American.$^{60}$ Despite this disproportionate number, racial issues manifested in several ways. The Corps was a segregated program, with separate camps for African American enrollees. However, often there were Black and white CCC camps operating at the same national park. Typically, Black CCC camps were administered by white supervisors, as was the case with Fredericksburg and Spotsylvania's Chancellorsville camp. Park records do not indicate that Black enrollees were given more menial or difficult jobs, but inequalities existed in other fashions Although the three camps set aside the same amount of time for educational opportunities for the enrollees, the two white camps seem to have a wider variety of educational programming. For example, selected white enrollees were given training to work as historical guides for visitors, whereas black enrollees were not given this option. Although having a black guide was never attempted, Superintendent Spaulding assumed that visitors would react unfavorably. In late 1939, when it appeared that the white Wilderness camp from which he was pulling guides was going to close, Spalding begged for the Chancellorsville camp to be replaced with a camp with white enrollees. Stating that it was "impossible" to use black enrollees as historical guides, he dramatically claimed that without white enrollees, his educational program would remain "virtually at a standstill.",61

\footnotetext{
${ }^{59}$ U.S. Department of the Interior, National Park Service, Gettysburg National Militayr Park, "Superintendent's Annual Report for Year 1936-1937," James R. McConaghie, Superintendent, pp. 7-11, File No. 207-01, Gettysburg, CCF, RG 79. Gettysburg National Military Park Archives.

${ }^{60}$ Exact figures vary by source. See Paige, The Civilian Conservation Corps and the National Park Service, 1933-1942, 97, and Salmond, The Civilian Conservation Corps, 89.

${ }^{61}$ Zenzen, 69-70, 83.
} 
Nationally, it was clear that African American camps could only be successful with local acceptance, which seemed unlikely as CCC director Robert Fechner was inundated with complaints for Black CCC camps to be removed. Attempts to stymie the criticism, such as the mandate that all African American enrollees must come from their own state and that the state's governor would select campsites, did little to alleviate local concerns. ${ }^{62}$ Local whites in Fredericksburg initially reacted strongly to the presence of an African American camp, as indicated by an article in the local newspaper, the Free Lance-Star. In this article, state senator C. O'Conor Goolrick argued that local protestors were "not objecting to the placing of the negroes in the county, but because they were brought here from the North," despite the fact that the majority of the enrollees were from Virginia. This could indicate that African Americans were automatically treated with more suspicion and seen as outsiders, even without a concrete reason. The park eventually had to issue an ultimatum to the local community, threatening to entirely abolish the Chancellorsville camp, which would cause the area to lose a large amount of economic benefits. When the 190 African American enrollees arrived, the Free Lance-Star grudgingly admitted that the men came from Richmond, Norfolk, and other areas of Virginia and "are used to our ways and customs." ${ }^{63}$ This probably meant that the enrollees were used to the state-sponsored segregation and oppression characteristic of the Jim Crow south, and therefore did not cause the disruption of a system revolving around white supremacy of which white locals were fearful.

African Americans enrolled at Gettysburg's Camp \#1355 had a highly unique experience. Although the camps were segregated by race like the majority of the nation, this particular camp

${ }^{62}$ Salmond, The Civilian Conservation Corps, 91-92.

63 "Defer Action on Negro C.C.C. Camp," Free Lance-Star, August 4, 1934; "Ultimatum says May Close Camps," Free Lance-Star, August 7, 1934; Quote made by T.C. Walker, as quoted in "Colored C.C.C. Men at Camp in Country," Free Lance-Star, August 8, 1934. 
was one of only two in the nation to have black commanders, and the only to have black technical personnel as well. ${ }^{64}$ Captain Frederick Slade, a U.S. Reserve Officer, was in command of this unit since 1936. An Illinois native and a graduate of the University of Illinois, he also had experience as a member of the Howard University ROTC. ${ }^{65}$ Slade was aided by other African American officers such as Dr. Louis E. King, the first African American historian in the National Park Service, as well as foreman Lane Lee and Educational Advisor Wallace Campbell. ${ }^{66}$ Numerous newspaper articles focus on the accomplishments of these leaders both before and during their tenure at Camp \#1355. For example, Lain Lee enrolled in the CCC "to help support his family," and had "acted as superintendent of the Sunday School, directed the camp chorus, wrote the company “Theme Song," taught elementary arithmetic and sign painting, pass examination in first aid with high honors, and was voted by other members of the company the most popular member in the camp. ${ }^{.67}$ Fifty of the enrollees were even selected to serve as guides, information clerks, and traffic directors during the $75^{\text {th }}$ anniversary events. ${ }^{68}$ In these articles, it is made clear that the achievements of these men were due to outstanding personal characteristics.

Because of the success of this entirely African American CCC camp, Camp \#1355 received much publicity in the press as evidence of the CCC's accomplishments in aiding impoverished African Americans. Some of these articles, such as those published in African

\footnotetext{
64 “Say Hospitality Rules CCC Camp No. 1355," Afro-American, May 18, 1940. ProQuest Historical Newspapers, January 12, 2015.

65 "First Colored CCC Commanding Officer Is Appointed," New Journal and Guide, August 15, 1936. ProQuest Histoical Newspapers, January 12, 2015.

66 “30,000 Race 'Timber Troops' in Anniversary Observance,” New Journal and Guide, April 10, 1937. ProQuest Historical Newspapers, January 12, 2015.

67 "Local Man Promoted to ECW Foremanship," The Pittsburgh Courier, February 15, 1936. ProQuest Historical Newspapers: January 12, 2015.

68 "Gettysburg CCC Co. Gets Park Ready for Celebration."
} 
American newspapers such as the Chicago Defender, are triumphal. In the article, "A Glimpse of a CCC Camp," a lengthy treatise on daily life within Camp \#1355, also known as Camp Renaissance, heavy emphasis is placed on the cleanliness and neatness of the camp. "In contrast to the rafters in most of the camps, which are usually unfinished, the beams in all the barracks at Camp Renaissance are done in black...The tables and benches are highly polished. ${ }^{, 69}$ Both the emphasis on order and the comparisons with other camps illustrate an attempt to prove that African American camps can function not only as well, but better, than white camps. Accomplishments of the enrollees were also emphasized, such as the publication of the biweekly newspaper the "Renaissance Journal," or the display of the company's "athletic prowess," including the boxing championship certificate awarded to former enrollee James Nichols, who went on to become a professional boxer. ${ }^{70}$ As much of the labor conducted by the enrollees was of a physical nature, it is unsurprising that physical success was lauded.

Educational opportunities afforded to the enrollees were extensively praised. However, instead of the courses in academic subjects and career skills often afforded to white enrollees, this coverage often focuses on the teaching of sanitation and "the rules of healthy living." Claiming that time in the CCC "has improved ethical standards of enrollees, friendly attitudes toward their fellows have been manifest, and the enrolee's[sic] life span has been lengthened," an article in the New Journal and Guide further states that one of the most important lessons learned by CCC enrollees is to respect authority. ${ }^{71}$ Again, the Gettysburg camp is cited as a successful experiment. Paternalistic at best, even this African American newspaper advances the

\footnotetext{
${ }^{69}$ Edgar G. Brown, “A Glimpse of a CCC Camp,” The Chicago Defender, June 8, 1935. ProQuest Historical Newspapers: Accessed January 12, 2015.

${ }^{70}$ Ibid.

71 "Youths Learn Really How to Live in C.C.C.," New Journal and Guide, June 26, 1937. ProQuest Historical Newspapers: Accessed January 12, 2015.
} 
idea that only "camp life has made young men realize that honesty and the opportunity to earn a livelihood is far better than any anti-social act which they may have been tempted to commit.",72 The successes of the Gettysburg camp were most likely used to waylay criticisms about the treatment of African Americans in the CCC. It is almost certainly no coincidence that Gettysburg, the site of Lincoln's famous address and the watershed battle in the war of emancipation, was chosen as the site for this particular camp. However, Camp \#1355 was the exception, not the rule.

Despite tensions and obstacles in the development of this commemorative environment, increased visitation in the late 1930s indicated that the NPS was successful in many of their goals. Visitation estimates to Fredericksburg and Spotsylvania jumped from 25,000 in 1934 to around 100,000 for the later years of the decade.$^{73}$ Gettysburg also experienced dramatic increase in visitation, as well as more geographic variation in the visitors it did receive. Superintendent's reports indicated that although the majority of visitors were still travelling from the state of Pennsylvania, it was "a customary thing to find at least twenty different States represented in the Park at one time. ${ }^{74}$ Visitation in the late 1930s increased to an average of 625,000 annual visitors, with an exceptional $1,554,238$ persons in fiscal year 1939 , due to the $75^{\text {th }}$ anniversary events. ${ }^{75}$ More people visiting the battlefields indicated not only ease of access but also

\footnotetext{
72 "Youths Learn Really How to Live in C.C.C."

${ }^{73}$ Zenzen, 88.

${ }^{74}$ U.S. Department of the Interior, National Park Service, Gettysburg National Military Park, "Superintendent's Annual Report for Year 1934-1935."

${ }^{75}$ U.S. Department of the Interior, National Park Service, Gettysburg National Military Park, "Superintendent's Annual Report for Year 1937-1938."
} 
broadness of appeal. Americans were not only able to visit these sites, but also encountered narratives and the landscape developed by the park service that were designed to be pertinent to their contemporary lives. Moreover, the landscape was now ready for major commemorative events coinciding with the $75^{\text {th }}$ anniversary of the war. These events, as well as experiences of the still-living Civil War veterans, will be explored in the final chapter.

As veterans and visitors alike arrived by train and automobile to participate in $75^{\text {th }}$ Anniversary commemorative events, they encountered battlefields greatly different from those just a decade previously. The administrative transfer of battlefields to the control of the National Park Service, manpower provided by New Deal Programs, and the declining influence of Civil War veterans all contributed to the dramatic changes of the 1930s. This pivotal decade saw the emergence of a modern battlefield landscape, concerned with providing the conveniences needed to facilitate mass tourism, while also improving educational opportunities and generating a "nineteenth-century" experience for the average visitor. In order to build this atmosphere, limited compromises with local communities were struck, while the visions of the veterans were largely obscured. Events surrounding the $75^{\text {th }}$ Anniversary not only represented a distinct interpretive and commemorative shift, but also illustrated that environmental history and Civil War memory are inextricably intertwined. The events of the 1930s show that battlefields are not static representations of the past, but instead reflections of contemporary society. Furthermore, these ideas and landscapes still have a profound influence on battlefield spaces today.

At Fredericksburg and Spotsylvania National Military Park, CCC storage sheds are used to house modern maintenance equipment. Stone letters denoting CCC camp MP-4 are obscured 
by the tall grass of the Wilderness battlefield's Saunders Field. Occasionally, a visitor finds an artifact belonging not to the Army of the Potomac or Army of Northern Virginia, but instead to Franklin Roosevelt's Tree Army. As evidenced above, the Civilian Conservation Corps and the early administration of the National Park Service left numerous intentional marks on America's Civil War battlefields. However, they left many unintentional signs of their presence as well. Both deliberate and accidental transformations to built battlefield landscapes continue to spark questions and debate into the twenty-first century, and the significance of these transformations transcends physical change. They represent not only the cultural climate of the 1930s, a time primed for vast environmental and educational change, but also offer a more thorough understanding of how commemorative spaces are built environments constantly in flux. Historical spaces consist of layers; layers that are not always harmonious, and do not always tell the same story. However, these layers allow for commemorative environments to remain a dialogue between groups of people with competing visions, past and present. 
Chapter 3: “There's Still Life in the Old Boys Yet:” Veterans, Living Monuments, and Usable Commemoration

Like a vestige of a bygone era, an elderly soldier in a dusty blue uniform once again set foot on a great killing field. Seventy-five years after the Battle of Gettysburg, Alvin T. Tolman, a Union veteran of the American Civil War, braved the oppressive July heat to participate in one final grand reunion. The first veteran to arrive, Tolman was confronted with a very different Gettysburg than the one remembered by the "Boys of '63." The landscape was perforated with monuments of all shapes and sizes, many of which were erected by the veterans themselves. However, much of what he saw in the town and surrounding battlefield was starkly different than the commemorative landscape envisioned by the old warriors. Tourists in automobiles clogged Gettysburg's narrow streets, as souvenir vendors prepared to take advantage of the reunion's commercial possibilities. Confronted by national press outlets armed with the latest model cameras, Tolman posed for a photograph shaking the hand of James McConaughie, the superintendent of the newly minted Gettysburg National Military Park. ${ }^{1}$ Over the course of the four days of ceremony, veterans would encounter the dedication of a monument far more imposing and institutional than those devoted to their fallen comrades, weapons far larger and more destructive than the rifles and cannons of the $1860 \mathrm{~s}$, and a presidential speech that applied their personal past experiences to the nation's current struggles. In their twilight years, Tolman and his fellow veterans had become part of a usable and shared national past.

The 1938 Gettysburg reunion was representative of a shift in the purpose of Civil War commemoration from one that existed primarily for the veterans and their descendants to one that was designed to appeal to the nation as a whole. The 1930s saw the emerging importance of

\footnotetext{
${ }^{1}$ Stan Cohen, ed., Hands across the Wall: The 50th and 75th Reunions of the Gettysburg Battle, 3rd rev. printing (Charleston, W. Va: Pictorial Histories Pub. Co, 1997), 53.
} 
environmental conservation and historic preservation, as well as the development of a national narrative of strength, heroism and enduring peace in reaction to the turbulence of the Great Depression and the rise of totalitarianism in Europe. These factors influenced the type and scale of commemoration at Civil War sites, and prior competing visions of veterans and their descendants were largely ignored or oversimplified to allow for the primacy of a shared national heritage. In the process, the Civil War became a much-needed triumphal tale belonging to the nation as a whole, and the remaining veterans were relegated to a secondary role as part of the commemorative landscape. Overall, commemorative efforts such as the ceremonies at Chancellorsville in 1935 and the final Gettysburg reunion of 1938 represents both an example of commemoration for a society in crisis as well as the unique challenges presented by a transitionary period in historical memory, when conflicting purposes for commemoration attempt to occupy the same physical and historical space.

Commemorations of war can serve many different purposes. One possible use of planned remembrance, particularly on the community or group level, is to aid with communal mourning. ${ }^{2}$ At other times, they can be used to advance an ideal, whether it is a unified national narrative or a resistant counter narrative. Commemorations can also romanticize a distant past in times of turbulence. In the years between the end of the American Civil War in 1865 and the $75^{\text {th }}$ anniversary of the battle of Gettysburg in 1938, commemorative efforts attempted all of these purposes, and all influenced the structure and content of the 1938 reunion. Over time,

\footnotetext{
${ }^{2}$ For more on commemoration used for mourning, see Daniel J. Sherman, “Art, Commerce, and the Production of Memory in France After World War I," in Commemorations: The Politics of National Identity, ed. John R. Gillis (Princeton, N.J: Princeton University Press, 1994), 186-207 and J. M. Winter, Sites of Memory, Sites of Mourning: The Great War in European Cultural History, Canto ed (Cambridge; New York: Cambridge University Press, 1998).
} 
commemorations shifted from the remembrances of veterans and their families and tributes to casualties, to wider remembrances encompassing the entire nation.

In the late 1860 s and 1870 s, the majority of veterans were focused on creating new lives in the post-war world. Therefore, northern and southern women spearheaded many of the commemorative efforts in the immediate post-war years. ${ }^{3}$ However, as veterans aged and memories became more distant, battlefield sites became increasingly popular locations for regimental reunions and monument building. In conjunction was the emergence of large veterans organization such as the Grand Army of the Republic (GAR) for Union veterans and the United Confederate Veterans (UCV) in the South. At this point, the GAR was a biracial organization which both commemorated the Emancipation Proclamation and the service of African American veterans. The GAR regularly held reunions at Gettysburg beginning in the 1870 s, soon joined by other small groups of veterans. ${ }^{4}$ The first monument outside of the National Cemetery was placed on the Gettysburg battlefield in 1878, a small stone placed by Pennsylvania veterans to mark the spot where their commander, Colonel Strong Vincent, was mortally wounded. Other markers to fallen leaders and comrades quickly followed, as well as numerous regimental markers. The majority of the battlefield's 1300 plus monuments were erected by veterans groups in the 1880s and 1890s. Dedicated either to fallen comrades or the soldiers' experiences, these monuments were highly personalized. Often, they were designed with symbols or made of material significant to the regiment and its locality, and they nearly always contained either the

\footnotetext{
${ }^{3}$ David W. Blight, Beyond the Battlefield: Race, Memory, \& the American Civil War (Amherst: University of Massachusetts Press, 2002), 177.

${ }^{4}$ Ibid.; Edward Tabor Linenthal, Sacred Ground: Americans and Their Battlefields, 2nd ed (Urbana: University of Illinois Press, 1993), 93-94.
} 
number or a listing of the casualties sustained by the unit. ${ }^{5}$ It was their way of both immortalizing their battlefield experience and their suffering.

Commemoration by former Confederate soldiers and their descendants also contained a powerful ideological component, which influenced Civil War memory for decades. Confederate memory of the Civil War centered on the myth of the Lost Cause. Faced with the stark failure of the Confederacy's war aims in 1865, the "architects" of what would become known as the Lost Cause sought to justify their wartime actions as well as providing their posterity with a "correct" version of the war. The Lost Cause would eventually distance the Confederate war aims from slavery, paint a counter-narrative of the war as an episode of overt Northern aggression, which the South lost not because of failed tactics but a disparity in resources, and elevate Confederate leaders such as Robert E. Lee to the status of national heroes. ${ }^{6}$ The emergence of this narrative has had a lasting effect on not only the Southern, but national, understanding of the Civil War.

The Battle of Gettysburg became highly significant to veterans in both blue and gray. This was largely due to the written reminiscences of veterans, which when read by other veterans influenced their collective identity. For the Union veterans, Gettysburg was characterized as a great turning point leading them down the path to Union victory. For the Confederate veterans, this loss represented both the "High Water Mark" of the Confederacy, the farthest north their army extended, as well as the ultimate expression of Southern valor in Pickett's Charge, the frontal assault launched against the Union army's established defensive position on the final day of the battle. ${ }^{7}$ Because of this shared importance, Gettysburg became the natural place for

\footnotetext{
5 Thomas A. Desjardin, These Honored Dead: How the Story of Gettysburg Shaped American Memory (Cambridge, MA: Da Capo Press, 2003), 153-59.

${ }^{6}$ Gary W. Gallagher and Alan T. Nolan, eds., The Myth of the Lost Cause and Civil War History (Bloomington: Indiana University Press, 2000), 1-3.

${ }^{7}$ Desjardin, These Honored Dead, 24, 41-46.
} 
attempts at joint commemoration. The first reunion of the Blue and Gray occurred in 1882, and over the next five years, at least nineteen more followed. These reunions began with modest pursuits such as marking the lines of battle, but eventually allowed veterans to focus on a shared experience of martial glory and honorable wartime conduct. These smaller reunions paved the way for the process of reconciliation, which would culminate in the semicentennial observances of $1913 .^{8}$

Reconciliation was an ideology, focused on the common experiences between the veterans of the blue and gray, that of collective heroism and a shared glorious past. This ideology dominated the fiftieth anniversary "jubilee" of the Battle of Gettysburg, and further emphasized the importance of binding sectional wounds. ${ }^{9}$ Over fifty-five thousand Union and Confederate veterans met at Gettysburg in 1913, listening to speeches that classified the heroism during the battle as "not Southern valor nor Northern valor, but American valor." ${ }^{10}$ Echoes of the Lost Cause can be seen in reconciliation, particularly in the near complete removal of slavery and African Americans from the standard narrative. ${ }^{11}$ Although this commemoration, and reconciliation as a whole, expands commemoration beyond the local or regional level to encompass a more national audience, it was still largely a veterans' story. The factor that allowed veterans of blue and gray to sideline sectional differences was their shared experience as soldiers, an experience that was not shared by the rest of the nation.

As the decade of the 1930s dawned, the influence veterans held over commemoration waned drastically. Aging bodies and dwindling numbers became the veterans' defining

\footnotetext{
${ }^{8}$ Paul A. Shackel, Memory in Black and White: Race, Commemoration, and the Post-Bellum Landscape (Walnut Creek, CA: Altamira Press, 2003), 29; Linenthal, Sacred Ground, 93.

${ }^{9}$ Linenthal, Sacred Ground, 95.

${ }^{10}$ Ibid., 96.

${ }^{11}$ Blight, Beyond the Battlefield, 182.
} 
characteristic in the media. Their steps were described as "feeble" and "faltering," their "bent and hobbling" figures struggled to walk a few blocks in a parade. ${ }^{12}$ Their experiences in both the 1860s and 1930s were oversimplified with blanket statements such as "they were old men yesterday, crippled by battle or by age, some half-blind, many deaf, but all proud of the past and happy in the present." ${ }^{, 13}$ Temporal distance from the war itself allowed for the veteran's wartime experience to be portrayed as not only superficially heroic, but something with which the aging warriors were prideful and content. However, the remaining living veterans were also seen as representing and memorializing those already lost, either to the war or to the seven intervening decades. This element of sacrifice became key to how Americans viewed the Civil War in the 1930s, as an event of just suffering that united the nation. This can be clearly seen in the theme for the $71^{\text {st }}$ annual encampment of the Grand Army of the Republic in 1937, which fewer than 200 veterans attended. The keynote event was a memorial ceremony dedicated to the theme of Abraham Lincoln, but the veterans" "first thought" was "for comrades who have gone before, and the opening of the five-day meeting was given over entirely to religious and memorial services." ${ }^{14}$ Governor La Follette of Wisconsin affirmed these views, stating "Although time has thinned your ranks, it has not dimmed the glory of your heroism and patriotic devotion." ${ }^{15}$ This combination of heroism and sacrifice would be used by politicians to promote a strong narrative of national unity, forged from the valor of Civil War soldiers.

12 "20 G.A.R. Men, Still 'on Parade,' Get Ovation in Memorial March," New York Times, May 31, 1934. Proquest Historical Newspapers: Accessed January 18, 2015.

13 "21 of G.A.R. March Valiantly in Rain in Tribute to Dead," New York Times, May 31, 1933. ProQuest Historical Newspapers, Accessed January 18, 2015.

14 "Survivors of G.A.R. Pay Tribute to Dead," New York Times, September 6, 1937. ProQuest Historical Newspapers: Accessed January 18, 2015.

${ }^{15}$ Ibid. 
Memorial Day exercises were another avenue through which veterans were consistently in the public eye, and this resulted in numerous comparisons with the younger veterans of other wars. Statements such as "the tap of canes and the gentle creak of crutches kept pathetic time to the blare of marching tunes and the clank of arms yesterday as the old and the disabled, veterans of Gettysburg and Bellau Wood," compared the ravages of age to the destructive horror of America's most recent war, in which North and South fought together. ${ }^{16}$ The juxtaposition of the old veterans with current military units was also seen as a warning. The overt destructiveness of the Civil War was underemphasized, and instead focus was once again placed on the heroism and just sacrifice of the boys in blue, especially when compared to the perceived futility of modern war. As statements such as "many units of the New York National Guard in field service uniforms gave the parade a grim hint of what modern day war might mean," grew in frequency as the decade drew to a close and tensions in Europe and Asia began to boil over, from "towns and hamlets throughout America there came fresh pledges...that the sacrifices made by those who gave their lives for their county should no be in vain." ${ }^{17}$ The still-living veterans became part of a usable past for a patriotic nation fearful of a new-armed conflict. This illustrates how Americans in the 1930s were looking to the past as assurance not only for present struggles, but also when looking forward into an uncertain future.

At this time, the media seems to have an almost-obsession with quantifying the remaining Civil War veterans. Estimated numbers such as "dozens" are never used to describe groups of veterans; instead, exact figures are almost always included. For example, when tracking the G.A.R.'s participation in New York City's Memorial Day exercises throughout the decade, the

16 "Thin Ranks of G.A.R. Cling to their Place in Memorial Parade," New York Times, May 31, 1932. ProQuest Historical Newspapers: Accessed January 18, 2015.

17 “Nation's War Dead Hailed in Services Here and Abroad," New York Times, May 31, 1939. ProQuest Historical Newspapers: Accessed January 18, 2015. 
rapid thinning of the ranks can be traced. The veterans who were able to walk in the parade numbered thirty-two in 1932 , twenty in 1934 , and only ten by $1939 .{ }^{18}$ Age was also quantified. Exact years were always used when describing individual octo- and nonagenarians, and even groups were described in precise manners such as "the youngest was 86 and the eldest 95 . The total of their ages is 1,797 years. ${ }^{19}$ Conversely, the small number of veterans allowed for common soldiers' stories to easily be told. Although personal information was usually relegated to the veterans' wartime experiences, the absence of still-living generals and officers allowed the heroism and sacrifice extolled by 1930s Americans to be that of the rank and file. For example, the "hobbled" figure of Robert Cain, "an aged Negro, one-time powder monkey under Farragut at New Orleans and Mobile Bay" who lost an eye during the war was mentioned in no less than three articles covering the Memorial Parades of three different years. ${ }^{20}$

Civil War veterans were nearly always presented as figures from another era, possibly even uncomfortable in modern times. When veterans were reunited, they created their own historical space. "And so," observed the New York Times, "the veterans of Vicksburg and of the Wilderness came into their own once more, came back to the world of living events from their days of dreaming of the glories of the past." ${ }^{21}$ Again, age is emphasized to the extreme, in some cases by the veterans themselves. Frank Hanley, 88, attended the parades every year with the purpose of ensuring his surviving comrades he was still alive, stating, "I'm an old fellow, and

18 "Thin Ranks of G.A.R. Cling to their Place in Memorial Parade."; "20 G.A.R. Men, Still 'on Parade,' Get Ovation in Memorial March," New York Times, May 31, 1934. Proquest Historical Newspapers: Accessed January 18, 2015. "Nation's War Dead Hailed in Services Here and Abroad, New York Times, May 31, 2015 ProQuest Historical Newspapers: Accessed January 18, 2015.

19 “'20 G.A.R. Men, Still ‘on Parade,' Get Ovation in Memorial March,” New York Times, May 31, 1934. Proquest Historical Newspapers: Accessed January 18, 2015.

20 "Thin Ranks of G.A.R. Cling to their Place in Memorial Parade."

${ }^{21}$ Ibid. 
lots of people think I'm dead...I may be dead in a couple of days, but I want 'em to know I'm alive now. ${ }^{, 22}$ Other instances of relegating the veterans to a bygone era were more poetic and romanticized, such as the New York Times' assertion that, "Each member of this little band of survivors of a war that is part of a vanished era has seen a whole lifespan of seventy years pass since his last battle was fought... Children unborn when they enlisted in Lincoln's time have died of old age, while they march on. ${ }^{, 23}$ The manner in which veterans were portrayed by the press in these smaller annual exercises was representative of the role they played in official commemorative efforts undertaken by the National Park Service.

As the $75^{\text {th }}$ Anniversary of the Civil War approached, numerous commemorative efforts at the local, state, and federal level were undertaken. Although the scale and success of these events varied, the largest and most publically supported were held on battlefields now under the umbrella of the National Park Service. This anniversary era not only represented massive transformations to the physical landscape as well as the final instances of Civil War veterans participating in large-scale remembrances, but also a tightening of federal control over battlefield commemoration which would continue to grow as the nation approached the centennial of the conflict. ${ }^{24}$ Some NPS officials such as Fredericksburg and Spotsylvania superintendent Branch Spalding felt that states like Virginia were having "too many historical celebrations," which spawned a "danger of loss of public patronage and a lowering of celebration standards." ${ }^{25} \mathrm{He}$, like many others, supported the creation of central committees to unify, and therefore somewhat

\footnotetext{
22 "21 of G.A.R. March Valiantly in Rain in Tribute to Dead."

23 "20 G.A.R. Men, Still 'on Parade,."”

${ }^{24}$ For more on the Civil War Centennial, see Robert J. Cook, Troubled Commemoration: The American Civil War Centennial, 1961-1965 (Baton Rouge: Louisiana State University Press, 2011).

25 "For Fewer Virginia Fetes," New York Times, July 12, 1936. ProQuest Historical Newspapers, February 24, 2015.
} 
control, commemorative efforts. Although the commemorations still contained powerful components of both reconciliationist attitudes and the Lost Cause mentality seen in prior expressions, the confluence of federally-promoted narratives of patriotic nationalism, enthusiastic tourist attendance on a massive scale, and the presence of living veterans create a commemorative environment much more complex than previous studies allow. Two cases of this multifaceted commemoration studied below are the smaller ceremonies at Chancellorsville in May of 1935 and the massive final Blue-Gray Reunion at Gettysburg in July of 1938.

Although held in 1935 , and therefore on the $72^{\text {nd }}$ Anniversary of the battle instead of the $75^{\text {th }}$, exercises on the Chancellorsville Battlefield that May are an exemplary case of Civil War battle commemoration in the 1930s, particularly in the South. With around 40,000 people in attendance, highlights included two addresses by prolific author Douglas Southall Freeman and a large sham battle with modern military cadets and equipment. Overall, the ceremony's narrative distinctly favored the Confederacy. Much of the commemoration focused on the personalities and maneuvering of Confederate generals Robert E. Lee and Thomas J. "Stonewall" Jackson, who were, by this point, mythic figures. Not only did accounts of the commemoration complement Jackson's Flank Attack as “one of the most daring manoeuvres[sic] ever attempted," but also cited the wounding of Jackson as "where the Confederacy suffered its greatest loss" which "paved the way for the final defeat of the Southern cause. ${ }^{, 26}$ Virginia Governor George C. Perry even went as far as to state that Chancellorsville was sacred ground because "it was stained by the blood of 'Stonewall' Jackson," with no regard to the other 30,000 casualties. ${ }^{27}$ The selection of locations for the commemorative events mirrored both the primacy

${ }^{26}$ Charles M'Lean, “40,000 See Battle of 'Blue and Gray,”' New York Times, May 3, 1935. ProQuest Historical Newspapers: Accessed January 20, 2015.

${ }^{27}$ Ibid. 
of the Confederate leaders in the park's overall narrative, but also land acquisitions. Sites acquired in the 1930s largely followed the Confederate lines of battle or held some importance to the Confederate High Command, such as the Stonewall Jackson Shrine, the building where the general died. ${ }^{28}$

The choice of Freeman as the keynote speaker further illustrated the Lost Cause undertones of the event. He gave two addresses, the first at the "Bivouac Stone," or the location of Lee and Jackson's last meeting, and the other immediately before the start of the sham battle. His words were filled with high drama, using phrases such as "Jackson vanished like a god into the wilderness on the morning of May $2^{\text {nd }}$. It was the last time that Lee saw him alive. ${ }^{.29}$ As in his books, Freeman focused on the leaders and military maneuvers of the battle, narrating the program with the use of huge maps. ${ }^{30}$ However, not only was the speaker influenced by Lost Cause mentalities, he was also not immune to reconciliationist rhetoric. Warning participants of the sham battle against a "too realistic demonstration," he claimed it unwise to place an American flag on either side, "for there is but one flag for us all from now on." ${ }^{, 31}$ Governor Perry also exhibited this conflating of ideas, advising that "justice and liberty, courage and honor, should continue to govern the new South just as it had governed the forefathers of those who took part in the demonstration," speaking to the idea of an honorable Lost Cause. However, he also cited the fact that the Chancellorsville battlefield was being developed by the federal government as "proof that this was a united country and never again would be split by such bitter feeling as existed prior to the Civil War."

\footnotetext{
${ }^{28}$ Zenzen, 98 .

${ }^{29}$ M'Lean, "40,000 See Battle of 'Blue and Gray."”

${ }^{30}$ Zenzen, 87.

${ }^{31}$ M'Lean, "40,000 See Battle of 'Blue and Gray."

${ }^{32}$ Ibid.
} 
This tension between the Lost Cause and Reconciliation can be seen clearly during the sham battle, and particularly in the crowd's reaction. Conducted on the historic battlegrounds by modern military entities using contemporary weapons, the sham battles of the 1930s were the exact opposite of the large-scale reenactments sanctioned by the Park Service in the $21^{\text {st }}$ century. The result was a spectacle. Eight hundred marines, representing the federal troops, stationed themselves behind historic artillery lunettes, with $75 \mathrm{~mm}$ guns, ready to stave off the advance of cadets from the Virginia Military Institute, who were exploding flare bombs to show "how close the Federal shots had missed the attacking 'Rebel' line." The "realism of the battle was so convincing" that a shell-shocked World War I veteran, five women, and one small child were all taken to the first aid station for treatment. The modern weaponry and formation of the advancing troops evoked not the atmosphere of the Civil War, but instead of World War I and the possibility of a modern conflict. ${ }^{33}$ However, the retreat of the "Federal" guns was enough to evoke a conflicted reaction from the audience. A weak shout at the first retreating guns was quickly stifled, "as if the spectators were loath to wound the sensibilities of visiting 'Northerners." However, as a Marine, or "Federal officer," waved a white cloth, the stands erupted in cheers, relishing in the recreation of the Confederate victory. ${ }^{34}$

Overall, Branch Spalding qualified the event as a success from the perspective of "education, memorialization, and park publicity," which outlined the goals of the ceremony as well. ${ }^{35}$ In addition to the lecture and the sham battle, thirty-six Marine airplanes dropped flowers onto the graves of those who had perished in the battle, while doing showy aerial maneuvers. ${ }^{36}$

\footnotetext{
${ }^{33}$ M'Lean, "40,000 See Battle of 'Blue and Gray"”

34 Ibid.

${ }^{35}$ Spalding, Memorandum to Director, Monthly Report for May 1935, June, 8, 1935, 1, File Admin History, Eric Mink Files, Fredericksburg and Spotsylvania National Military Park. ${ }^{36}$ Zenzen, 88.
} 
These seemingly strange exercises had the dual effect of memorializing past military events while exhibiting current martial strength. The veterans of the Civil War had a very limited role in the Chancellorsville commemoration, which was planned as a collaboration between the NPS and ten local members of the Fredericksburg National Battlefield Park Association. ${ }^{37}$ The Confederate veterans in attendance were largely on the periphery, observing the ceremonies but not taking an active role in the planning or execution. ${ }^{38}$ Like monuments, they were given little attention, seen as passive reminders of the past, even as part of the historical landscape. However, another commemorative effort at Gettysburg three years later would, while still treating them to some extent as living monuments, place the veterans into a much more central role.

Murmurings about the possibility of a final reunion of the blue and gray began early in the 1930s, and the $75^{\text {th }}$ anniversary of the battle of Gettysburg was settled on as an appropriate time. Planning for the event began in 1935, when both federal and state commissions were formed. Extensive planning in the next two years resulted in a highly ambitious commemoration that would cater to both the dwindling number of veterans and the tens of thousands of tourists expected to attend..$^{39}$ Of the over 10,000 invitations sent, 1,845 veterans were able to reach Gettysburg to once more commemorate the defining four years of their generation. ${ }^{40}$ Fewer than fifty had actually participated in the Battle of Gettysburg, but by 1938 the primacy of this one battle was firmly entrenched in the veterans' collective consciousness. ${ }^{41}$ Joint funding from the

\footnotetext{
${ }^{37}$ Zenzen, 88.

${ }^{38}$ Spalding, Memorandum to Director, Monthly Report for May 1935, June, 8, 1935.

${ }^{39}$ Cohen, Hands across the Wall, 40-41.

${ }^{40}$ Mitchell Yockelson, "The Great Reunion: The Seventy-Fifth Anniversary of Gettysburg," Prologue, Summer 1992, 188, V11-62, Gettysburg National Military Park.

41 "The Blue and Gray: Age Mellows Memories on Seventy-Fifth Gettysburg Anniversary," Newsweek, July 11, 1938, V11-62, Gettysburg National Military Park.
} 
federal and state commissions paid for each veteran's train fare to and from Gettysburg, as well as the travel expenses of one attendant, usually a family member, who would be responsible for caring for the veteran. The nearly 7,000 people were housed in a "tent city" constructed of nineby-nine military wall tents equipped with the necessities for living for three to five days. ${ }^{42}$ The commemoration itself consisted of a four-day program. July $1^{\text {st }}$, opening day, largely involved speeches by dignitaries welcoming the veterans to Gettysburg. The next day was called "Veterans Day," which comprised of a parade of the regular army through town, reviewed by Civil War veterans and veterans of later wars. July $3^{\text {rd }}$ centered on the dedication of the Eternal Light Peace Memorial, and President Franklin Roosevelt's accompanying speech. The final day was an overt show of modern military technologies. ${ }^{43}$

In the study of Civil War memory, the 1938 Reunion has often been ignored or oversimplified as nothing more than an extension of the reconciliationist fervor of 1913. In reality, this anniversary was much more complicated, and differed from the semicentennial commemoration in many ways. The impetus for organizing this reunion was not from the veterans or the veteran's organizations, but from local and state commissioners under the leadership of Gettysburg Chamber of Commerce Executive Secretary Paul Roy. Hoping to renew interest in the lucrative practice of reunions and monument building which characterized the late $19^{\text {th }}$ century, Roy saw the anniversary as an opportunity to "sell" Gettysburg to the nation. ${ }^{44}$ Obviously, a considerably smaller number of veterans attended the $75^{\text {th }}$ Anniversary in comparison to the $50^{\text {th }}$, but another key difference lay in the significantly larger number of

\footnotetext{
${ }^{42}$ Cohen, Hands across the Wall, 41.

43 "Program: 75th Anniversary Battle of Gettysburg, Final Reunion of the Blue and Gray" (Gettysburg National Military Park, July 29, 1938), V11-62c, Gettysburg National Military Park Archive.

${ }^{44}$ Weeks, Gettysburg, 133-34.
} 
tourists in 1938. Automobile travel, improved highways, and increased focus on catering to families ensured both access to Gettysburg and an enjoyable experience upon arrival.

Interactions between the visiting families and the few remaining elderly veterans were largely for the benefit of the tourists searching for an authenticated experience of the past. ${ }^{45}$ In many ways, veterans became integral to creating a unique experience for visitors as part of a commemorative landscape.

It is true that media outlets and politicians continued to perpetuate a narrative of unity. For example, the Christian Science Monitor claimed that this reunion had the opportunity to prompt the "disappearance of a remnant of sectionalism and the emergence of a wider sense of patriotism that forgives - and forgets - the separating bitterness of $1861-1865 .{ }^{, 46}$ Many of the veterans seemed to support this attitude, or were at least quoted by the media as doing so, such as ninety-three year old Confederate veteran William H. Freeman, of Wetumka, Oklahoma, who explained to a reporter, "We're here to bury the hatchet and forget all about that little fus," and his companion, a Union veteran who sentimentally replied, "We've done that long ago.",77 However, reconciliation itself is an oversimplification, as many of the veterans did not share what has come to be seen as a pervasive movement towards a shared heroic past. When extending invitations to the remaining veterans organizations, Roy had trouble convincing both the United Confederate Veterans and the Grand Army of the Republic that a final reunion would be beneficial. Many officials of the G.A.R. still held bitterness toward the Confederate invasion of the north, and General Harry Rene Lee, leader of the UCV, went as far as to exclaim "Young

\footnotetext{
${ }^{45}$ Weeks, 154.

${ }^{46}$ Linenthal, Sacred Ground, 96.

47 "Here and There with the Vets.," Star and Sentinel, July 9, 1938, http://news.google.com/newspapers?id=pYklAAAAIBAJ\&sjid=uflFAAAAIBAJ\&pg=11\%C2\% $\mathrm{A} 0 \% \mathrm{C} 2 \% \mathrm{~A} 0 \% \mathrm{C} 2 \% \mathrm{~A} 0 \% \mathrm{C} 2 \% \mathrm{~A} 0 \% \mathrm{C} 2 \% \mathrm{~A} 0 \% \mathrm{C} 2 \% \mathrm{~A} 0 \% \mathrm{C} 2 \% \mathrm{~A} 0 \% \mathrm{C} 2 \% \mathrm{~A} 0 \% \mathrm{C} 2 \% \mathrm{~A} 0 \% \mathrm{C} 2 \% \mathrm{~A} 0 \%$ C2\%A0, Google News Archive.
} 
Man, I thought you would come down here and try to get my organization to go to Gettysburg to meet with those damnyankees... The answer is no, emphatically and positively no."48 While both organizations eventually gave their support, their initial reactions illustrate that sectional bitterness was by no means relegated to a distant past in 1938.

Certain aspects of the reunion also spoke to the predominance of sectionalism in interactions between the old soldiers. Ninety-four year old Union veteran David Reed believed it was unsafe for veterans to carry guns, as though the only barrier between reunification and sectional bitterness was the lack of weapons. ${ }^{49}$ Although both Union and Confederate flags were presented to each veteran upon arrival, debate over the use of the Confederate flag existed. For example, GAR representative James Willett referred to it as "the infernal banner," and many took up the battle cry "No rebel colors!",50 This certainly did not speak to the generalization that the veterans now existed as comrades "without heed for stars and stripes, or stars and bars.",51 A less venomous account of sectional confusion came from Annette Tucker, who was participating in the reunion as her father's attendant. She described in her account of the commemoration that displaying the Confederate flag at the reunion "didn't seem the proper thing to do," but that she brought it home to "perhaps use at our own U.D.C. [United Daughters of the Confederacy] Meetings." 52 This illustrated that the feeling of unity present at the reunion did not necessarily have permanence throughout the nation. Even organizational choices such as having separate

\footnotetext{
${ }^{48}$ Yockelson, "The Great Reunion: The Seventy-Fifth Anniversary of Gettysburg," 190.

49 "Old Blues, Grays Become One for 75th Reunion at Gettysburg," The Washington Times, July 4, 1992, V11-62, Gettysburg National Military Park Archives.

${ }^{50}$ Excerpt from Lowell Thomas broadcast of September 9, 1937, Cohen, Hands across the Wall, 40.

${ }^{51}$ Paul Martin, "Civil War Vets Hold Last Camp: Two Thousand Men of Blue and Gray Swap Takes in Reunion at Gettysburg"," Rocky Mount Herald, July 1, 1938, V11-62, Gettysburg National Military Park Archives.

${ }^{52}$ Annette Tucker, “The Gettysburg Reunion,” n.d., 4, V11-62, Gettysburg National Military Park Archives.
} 
Union and Confederate camps, or the fact that the majority of the veterans chose to wear their old uniforms, subtly implied that divisions between the two sides still existed. ${ }^{53}$ Furthermore, the motivations for veterans to attend the reunion were not necessarily geared towards reconciliation, or even idealistic at all. African-American veteran Frank Lilley may have come to show that the Civil War was not only a white experience, as the reconciliationist narrative suggests. ${ }^{54}$ Many came to reunite with old comrades they had not seen in years. Another veteran stated that he travelled to Gettysburg to find a tree, explaining, "I was wounded near that tree, and all I want in this world is to find it. When I do, then I'll be ready to die." ${ }^{55}$ Even this small group of veterans was not monolithic in their intentions for and assigned significance of the reunion.

Another unique and highly significant characteristic of media coverage concerning the $75^{\text {th }}$ Anniversary was the overemphasis of the veterans' age. The average age of the attending veterans was ninety-four, and they were all aware that this would be the final Gettysburg reunion. ${ }^{56}$ The "tent city" provided for the veterans comfort as much as possible, including a fully functional hospital and over four hundred wheelchairs, complete with Boy Scouts and National Guardsmen to push them. ${ }^{57}$ Many veterans invited were forced to decline attending due to poor health, and others were truly risking their lives in order to reach Gettysburg. ${ }^{58}$ However, despite the reality that the remaining Civil War veterans were nearing the end of their lives, the language media outlets stressed this impending mortality far more than necessary. Terms such as

\footnotetext{
${ }^{53}$ Cohen, Hands across the Wall, 41.

${ }^{54}$ Lawrence A. Kreiser and Randal Allred, eds., The Civil War in Popular Culture: Memory and Meaning (Lexington, Kentucky: University Press of Kentucky, 2014), 68.

55 "The Blue and Gray: Age Mellows Memories on Seventy-Fifth Gettysburg Anniversary."

${ }^{56}$ Linenthal, Sacred Ground, 97.

${ }^{57}$ Cohen, Hands across the Wall, 58, 44.

${ }^{58}$ Ibid., 41-42.
} 
"old-timers," "hobbling," and "feeble" were common. ${ }^{59}$ One article even commented that the reunion "crowded out the thought that the time is closing in and that the remnants of the once proud Union and Confederate armies soon must join their comrades. ${ }^{, 60}$ This characterization seemed to survive the ensuing decades, as an article about the anniversary in 1979 referred to it as the "graybeard reunion." ${ }^{\text {61 }}$ However, even more damaging was the presentation of the veterans as not only aging, but also cartoonish and childlike. One headline stated that the "Gettysburg Camp Grand Talk Fest for Veterans," which went on to describe a ninety-five year old Confederate doing a 'lively buck and wing dance," as well as implying that the only modern day issue concerning Philadelphia resident Allen T. McFarland is the outcome of the PhilliesGiants baseball game. ${ }^{62}$ Another emphatically exclaimed "There's Still Life in the Old Boys Yet!” and portrayed Union veteran Tim Flaherty dancing a jig for his comrades, with an accompanying photograph. ${ }^{63}$ Articles such as these romanticize veterans at best and portray them as one-dimensional and simplistic at worst. Even more significantly, the emphasis on age implies that veterans belong to a past era, instead of as a part of modern society.

The oversimplification of the veterans' experience at the 1938 reunion, as well as attempts to assign these still living men to the annals of history, was a byproduct of the shifting of the Civil War from a lived memory experienced by few to a collective heritage experienced by

59 "Veteran Leaders Plead for Peace: Spirit of Fellowship Prevails at Gettysburg; Woodring Lauds Old-Timers"," News and Observer, July 2, 1938, V11-62, Gettysburg National Military Park; "President Makes Eloquent Appeal for World Peace," News and Observer, July 4, 1938, V11-62, Gettysburg National Military Park; Martin, "Civil War Vets Hold Last Camp." 60 "Veterans Depart from War Scene: Say Sad Farewells as Their Last Reunion Comes to End at Gettysburg," News and Observer, July 6, 1938, V11-62, Gettysburg National Military Park.

${ }^{61}$ Jeremiah O'Leary, “Gettysburg Revisited and Remembered," Washington Star, July 5, 1979, V11-62, Gettysburg National Military Park.

${ }^{62}$ Harry G. Proctor, "Gettysburg Camp Grand Talk Fest for Veterans," The Evening Bulletin, July 1, 1938, V11-62b, Gettysburg National Military Park Archive.

63 “"There's Still Life in the Old Boys Yet!," The Morning Herald, July 4, 1938, V11-62, Gettysburg National Military Park. 
all. As David Lowenthal argues in Identity, Heritage, and History, "history co-opted by heritage" tends to over exaggerate certain facts, such as the age or simplicity of veterans, to create an ancestry usable to "confirm identity and boost the solidarity" of modern society. ${ }^{64}$ The $75^{\text {th }}$ Anniversary at Gettysburg is a watershed in Civil War memory, providing both the last example of commemoration for and by veterans, and the first truly national commemorative experience. President Roosevelt's letter to Pennsylvania Senator John S. Rice in September of 1936 predicted this shift even when the event was still in its planning stages. He wrote that the $75^{\text {th }}$ anniversary was a tribute to the heroism and sacrifice of the participants on both sides of that great combat, and although "few remain who wore the blue or the gray on that historic occasion...the valor and nobility of the soldiers who fought there will ever live among our cherished traditions." ${ }^{.65}$ There was a duality to the 1938 reunion and celebration not present in other anniversaries because the time in which it occurred would not allow it to be one or the other.

By 1938 , technological advances allowed the $75^{\text {th }}$ anniversary of the Battle of Gettysburg to be experienced on a truly national level. Infrastructure developments such as improved road networks, as well as the rise of automobile tourism, allowed for an estimated 775,000 individuals to attend the commemorative events. ${ }^{66}$ Others were able to experience the occasion remotely, through the extensive media coverage by newspapers, magazines, radio, and even newsreels. In

\footnotetext{
${ }^{64}$ David Lowenthal, "Identity, Heritage, and History," in Commemorations: The Politics of National Identity, ed. John R. Gillis (Princeton, N.J: Princeton University Press, 1994), 53, 4446.

${ }^{65}$ Letter from Franklin D. Roosevelt to John S. Rice, September 8, 1936 in "Visit Gettysburg: Blue and Gray Reunion, 75th Anniversary Battle of Gettysburg 1938" (Gettysburg, PA, 1938), 7, V11-62c, Gettysburg National Military Park Archive.

${ }^{66}$ Weeks, Gettysburg, 154; Unrau, "Administrative History: Gettysburg National Military Park and National Cemetery, Pennsylvania," 183.
} 
total, over one hundred journalists covered the anniversary ${ }^{67}$ The sheer pervasiveness of the coverage of this event proclaimed it as historic, and the consistency of the reporting allowed the event to influence Americans' previously held notions concerning the Civil War in order to form a more cohesive collective narrative. ${ }^{68}$ In July 1938 , the nation was saturated with news concerning the Battle of Gettysburg and its significance, perhaps for the first time since the battle itself.

Fittingly, the only monument dedicated in 1938 was both an expression of romanticism and the dual purpose of the commemoration in general. The "Eternal Light Peace Memorial," unveiled with much pomp and circumstance at the closing of events on July $3^{\text {rd }}$, was dedicated to "the memory of every man, woman and child, North and South, who participated in any way in the War Between the States," as well as a "perpetual symbol of peace." ${ }^{, 69}$ The design of the memorial was institutional, imposing, and vastly different from the monuments erected by the veterans in preceding decades. ${ }^{70}$ Composed primarily of a forty-foot limestone shaft resting on an enormous platform, the monument towers over the battlefield. Two allegorical female figures, representing North and South, stand beside an eagle, a symbol of the united nation. Unlike regimental or state monuments erected by veterans, this behemoth structure contains no mention of casualties, by either name or number. In fact, the only name mentioned on the monument at all

\footnotetext{
${ }^{67}$ Weeks, Gettysburg, 134.

${ }^{68}$ For more concerning the influence of media events on collective memory, see Daniel Dayan and Elihu Katz, "Media Events: The Live Broadcasting of History," in The Collective Memory Reader, ed. Jeffery K. Olick, Vered Vinitzky-Seroussi, and Daniel Levy (New York, N.Y: Oxford University Press, 2011), 362-63.

69 "Visit Gettysburg," 18.

70 "Eternal Light Peace Memorial at Gettysburg," accessed April 28, 2014, http://www.gettysburg.stonesentinels.com/Other/Peace.php; "75th Anniversary, Battle of Gettysburg [0125] - Unveiling of the Eternal Light Peace Memorial :: Civil War Reunions and Reminiscences," accessed April 28, 2014, http://gettysburg.cdmhost.com/cdm/singleitem/collection/p15059coll5/id/296/rec/125.
} 
is that of Abraham Lincoln, along with the quote, "With firmness in the right as God gives us to see the right." At the top of the memorial is the gas-lit eternal flame, accompanied by the words "An enduring light to guide us in unity and fellowship."71 This monument utilized both the legacy of Lincoln and Civil War veterans as models for future generations. Although this monument was intended to be the "final tribute of honor and respect" the nation would pay to "these men of courage," it is clear that the only permanent structure to emerge from the 1938 reunion was intended for posterity. ${ }^{72}$

Superficially, the Eternal Light Peace Memorial and its dedication are tangible representations of reconciliation. Engraved with the words "Peace Eternal in a Nation United," the monument was draped in a huge American flag for its July $3^{\text {rd }}$ unveiling. Two veterans, one Union and one Confederate, helped uncover the monument while the other veterans watched from a special sheltered grandstand. ${ }^{73}$ Roosevelt's concise, nine-minute speech contained lines such as "All of them we honor, not asking under which flag they fought then - thankful that they stand together under one flag now." ${ }^{, 74}$ Roosevelt's speech was not only heard by the 200,000 individuals in attendance, but also broadcast on national radio. ${ }^{75}$ Not only did the press seize this message, but the light's dedication seemed to have a profound effect on those in attendance as well. Annette Tucker, the daughter of a Confederate veteran who had grappled with the appropriate time to display a Confederate flag earlier during the commemoration, wrote, "Since we have lighted the Peace Memorial, I don't see any use in displaying it at all. In the language of

\footnotetext{
71 "Eternal Light Peace Memorial at Gettysburg."

72 "Visit Gettysburg," 18.

${ }^{73}$ Linenthal, Sacred Ground, 97; Cohen, Hands across the Wall, 44.

74 "Franklin D. Roosevelt: Address at the Dedication of the Memorial on the Gettysburg Battlefield, Gettysburg, Pennsylvania.," accessed April 28, 2014, http://www.presidency.ucsb.edu/ws/?pid=15669.

${ }^{75}$ Linenthal, Sacred Ground, 97.
} 
the march I say, 'The Stars and Stripes forever.","76 As perhaps the only truly reconciliationist monument on the Gettysburg battlefield, and certainly the most obvious, it is not surprising that the legacy of the 1938 reunion has been generalized.

However, this monument's significance goes beyond lauding past compromise. It is both a commentary on the current challenges faced by the United States in the 1930s and a projected hope for the nation's future. By stating, "Immortal deeds and immortal words have created here a shrine of American patriotism," Roosevelt not only placed the story of Gettysburg into the triumphal narrative of American history, but also created the ability for Gettysburg's legacy to be applied to current issues, present and future. ${ }^{77}$ Asserting that although the challenge of preserving democracy takes different forms for different generations, perhaps alluding to the test of democracy presented by totalitarian regimes in 1930s Europe, the president then used the legacy of Civil War veterans to call "upon the nation to dedicate itself to eternal struggle for peace through democracy." ${ }^{, 78}$ The press seized this theme as well, with headlines crying, "Gettysburg Vets Saved Great Democracy for the World," and connecting this ancestral legacy as the guardians of democracy to the belief that "Americans today are the trustees of popular liberty for the whole world." ${ }^{, 79}$ The application of the struggles of veterans during Civil War to current issues, and the idea that the veterans' legacy was that of enduring peace, created from the Civil War a usable national past.

\footnotetext{
76 Tucker, "The Gettysburg Reunion," 4.

77 "Franklin D. Roosevelt: Address at the Dedication of the Memorial on the Gettysburg Battlefield, Gettysburg, Pennsylvania."

78 "President Makes Eloquent Appeal for World Peace."

79 "Gettysburg Vets Saved Great Democracy for the World," Philadelphia Record, July 4, 1938, V11-62b, Gettysburg National Military Park; "President Will Dedicate Gettysburg Light Today," News and Observer, July 3, 1938, V11-62, Gettysburg National Military Park.
} 
In sharp contrast to the overture to peace on the evening of July $3^{\text {rd }}$ was the flagrant display of American military might on July $4^{\text {th }}$. Appropriately characterized as a "monster military parade" by the Philadelphia Inquirer, the display included demonstrations of modern weaponry such as tanks, cavalry and artillery demonstrations, and even air shows. ${ }^{80}$ This show of martial strength seems very odd when juxtaposed with the dedication of the Peace Light the day before, alluding to the idea of peace by force. Again, this commemorative exercise placed the veterans firmly in the past. The "guests of honor," surrounded by elaborate decorations reminiscent of a presidential inauguration, they watched "demonstrations of arms beside which their ancient muskets and muzzle-loading cannon were mere toys." ${ }^{\circ 1}$ The event culminated in a strange depiction of how Pickett's Charge would have been conducted in 1938, including modern infantry formations and showy aerial maneuvers. ${ }^{82}$ A strange merging of past and present, a romanticized landscape of past martial glory was infiltrated by physical representations of current military strength.

By the end of July 4, 1938, the few remaining veterans in the blue and gray had been positioned firmly into antiquity, and the nation was well on its way to embracing the American Civil War as a collective experience. The events of the 1938 reunion mirrored the shift from veterans' commemoration to modern commemoration for the nation. From the oversimplification and romanticization of the veterans' lived experiences, to the eventual incorporation of that lived experience into an identity of liberty, peace, and national glory shared by all Americans, the $75^{\text {th }}$ anniversary of the Battle of Gettysburg was far more complicated and noteworthy than for which

\footnotetext{
${ }^{80}$ Cohen, Hands across the Wall, 45.

81 "Veterans Enjoy Army Spectacle: Modern Fighters Stage Spectacular Maneuvers for Heroes at Gettysburg," News and Observer, July 5, 1938, V11-62, Gettysburg National Military Park Archives.

${ }^{82}$ Ibid.
} 
previous studies allow. The veterans' departure from Gettysburg at the end of the anniversary, never to return, represented the end their direct influence on the commemoration of the battle. Although remnants of the veterans' remembrance certainly remain, specifically the numerous monuments dotting the landscape, their experience could now be used as a historical basis for modern, and sometimes contradictory, identities and ideologies without challenge. Overall, the 1938 Gettysburg reunion and $75^{\text {th }}$ anniversary events illustrated how the commemoration of wars are complicated by the fading of a lived veterans experience in conjunction with the emergence of a shared collective heritage, as well as the appropriating of historic events by a society in crisis in order to promote a strong national narrative.

The National Park Service was the stage, the $75^{\text {th }}$ Anniversary the setting, for an era of complex and at times unspoken commemorative conflict. The expansion of national tourism to include Civil War battlefields, and the shift in organization and focus of the administration of these battlefields, allowed for both Gettysburg and Fredericksburg and Spotsylvania to become spaces in which to educate Americans about a shared national heritage. However, the significance of battlefield commemoration in the 1930s extends beyond the complicated advancement of a narrative of unity through sacrifice, struggling to exist beside elements of sectionalism and the Lost Cause. It exhibits the ability of societal leaders to select elements of the past best suited for the needs of an uneasy nation looking towards the future. It is also the era that perhaps best exemplifies the pivotal roles built landscapes and the physical environment has on battlefield interpretation and commemoration. Finally, it epitomizes the unfortunate tendency of societies to treat aging veterans of past conflicts not as active agents but as relics of an unknowable past, or even as part of the commemorative landscape itself. Overall, the $75^{\text {th }}$ Anniversary of the Civil War within the context of the National Park Service shows that 
commemorative conflict occurs not only with the presence of culture wars and loud, dissenting voices, but also with the discreet obliteration of preceding physical and ideological layers of remembrance. 
Epilogue: "All war, the old and the new, is alike."

The Gettysburg of July 1943 was vastly different than that of 1938 . No crowds of hundreds of thousands of tourists clogged the streets on foot or by automobile. No presidential speeches or dedications of imposing memorials occurred. No elderly veterans encamped on the old killing fields. The only soldiers on the streets were modern, and their military equipment served a very different purpose than a reenacted sham battle. America was now a nation at war. Although "the old war has not perished from men's thoughts," especially on the deceptively peaceful fields of Gettysburg, "the new war reveals itself in the lonesomeness of the battlefield, where few visitors go any more or will go for the duration." ${ }^{1}$ Vague allusions to the possibility of new conflict made at the $75^{\text {th }}$ Anniversary had become reality by the $80^{\text {th }}$. The landscape of war had once again changed.

"All war, the old and the new, is alike," wrote journalist R.L. Duffus as he traversed the quiet field. "One realizes this, too, as one walks along the historic lines, and the dead men come to life. All war is passion. All war is conquest of fear. All war is a stifling of the instinct to survive." The sacrifice praised just five short years ago takes on a new meaning. Not only was the battlefield a symbol of the righteous sacrifice of generations past. Now, the nation faced the loss of thousands of its young men and women, sacrificed on the alter of democracy once again. "All war is the death of young men before their time. Gettysburg knows the new war because it has lived so long in the unforgettable presence of the old.",2

\footnotetext{
${ }^{1}$ R. L. Duffus, “"The World...Can Never Forget," New York Times, July 4, 1943. ProQuest Historical Newspapers, March 13, 2015.

${ }^{2}$ Ibid.
} 
This was not the war of the blue and gray. Although those still living almost certainly had their opinions, hopes, and fears about the outcome, this was not the defining moment of their generation. This was the war of eight hundred and seventy-seven men and women from Gettysburg College are in the armed forces. ${ }^{3}$ It was the war of the Civilian Conservation Corps enrollees who had built the roads and fences, planted the trees, and explained to visitors the significance of the old battlefield. It was the war of the National Guardsmen who had the difficult job of controlling the massive crowds in 1938, and even the war of the Boy Scouts who pushed the veteran's wheelchairs.

This was the war of an elderly veteran who fought on the beaches of Iwo Jima, who in 2013 stood in an echoing, blue-tinted room at the National Museum of the Marine Corps, next to an exhibit on that very battle. He waited patiently for a group of visitors to finish watching a short film on the action, and then delivered a pre-rehearsed, three-minute speech about his wartime experience. All listened politely. Many were touched. A few thanked him for his service. No one took the opportunity to ask him any further questions. All moved on to the next exhibit. And he continued to stand in that echoing room, blending into the space as if he were just another artifact.

"All war, the old and the new, is alike."

We are rapidly approaching the $75^{\text {th }}$ anniversary of the Second World War, and with this come questions perhaps all $75^{\text {th }}$ anniversaries produce. Although the great battlefields of this war are all overseas, this certainly does not mean we have not created commemorative landscapes within the United States. There are exhibits such as the one described above. There are monuments such as the behemoth World War II Memorial on the National Mall. There are even

${ }^{3}$ Duffus, “’The World...Can Never Forget.” 
national parks, as sites such as Rosie the Riveter/World War II Home Front National Historic Park and Manzanar National Historic Site show the nuances of the World War II narrative. However, there are also more ephemeral ceremonies surrounding the veterans themselves. Hobbling, gray-haired figures march in Memorial Day parades. Old men fly overseas to visit the beaches they last saw with the eyes of youth. We conduct oral histories on an unprecedented scale. We read books and watch movies based on their experiences. We read their obituaries. We overemphasize their age.

Thus far, veterans of World War II have shaped the commemoration of their generation's defining conflict. The question is, will we continue to let them? Or will they become, as did the boys in blue and gray, nostalgic living memorials of a bygone era.

"All war, the old and the new, is alike." Perhaps their commemorations are as well. 


\section{Bibliography}

\section{Primary Sources:}

\section{Published Sources:}

Albright, Horace M., and Frank J. Taylor. “Oh, Ranger!” A Book about the National Parks, Revised Adddition. New York: Dodd, Mead \& Company, 1947.

"Fredericksburg and Spotsylvania County National Military Park Virginia. United States Department of the Interior, 1942.

"Gettysburg National Military Park Pennsylvania. United States Department of the Interior, 1940."

Harper, Charles Price. The Administration of the Civilian Conservation Corps. Clarksburg, WV: Clarksburg Publishing Company, 1939.

"Jackson Memorial Wild Flower Preserve." Fredericksburg and Spotsylvania National Military Park. May 20, 1938. VF 123. Fredericksburg and Spotsylvania National Military Park.

"Manasses to Appomattox: National Battlefield Park Tour in Virginia." United States Department of the Interior, 1940. VF 123. Fredericksburg and Spotsylvania National Military Park.

Minnigh, Luther W. Gettysburg: What They Did Here. Gettysburg, PA: Tipton and Blocher, 1924

Oliver, Alfred C., Jr., and Harold M. Dudley. This New America: The Spirit of the Civilian Conservation Corps. New York: Longmans, Green and Co., 1937.

"Program: 75th Anniversary Battle of Gettysburg, Final Reunion of the Blue and Gray." Gettysburg National Military Park, July 29, 1938. V11-62c. Gettysburg National Military Park.

Wert, J Howard. A Complete Hand-Book of the Monuments and Indications And Guide to the Positions on the Gettysburg Battle-Yield, 5.

\section{Manuscripts:}

Branch of Historic Sites, Gettysburg National Military Park Master Plan, 1939, September 2, 1939, GNMP Library

Coolidge, Calvin. "Text of 1928 park dedication speech." BV-492. Fredericksburg \& Spotsylvania National Military Park. 
Department of the Interior, National Park Service, "Annual Report for the Gettysburg National Military Park, Year Ending September 30, 1934," RG 79, E 411, Box 2493, National Archives and Records Administration.

Department of the Interior, National Park Service, "Superintendent's Annual Report for the Year 1935-1936," by James R. McConaughie, RG 79, E 411, Box 2493, National Archives and Records Administration.

“Eternal Light Peace Memorial at Gettysburg.” Accessed April 28, 2014. http://www.gettysburg.stonesentinels.com/Other/Peace.php.

FRSP Annual Report, Fiscal Year 1938, 4, File 207 Reports, Box 2468, RG 79, NARAArchives II.

FRSP Photo Files

"Franklin D. Roosevelt: Address at the Dedication of the Memorial on the Gettysburg Battlefield, Gettysburg, Pennsylvania." Accessed April 28, 2014. http://www.presidency.ucsb.edu/ws/?pid=15669.

Gettysburg Battlefield Memorial Association: Its Organization, Plans and Purposes ([Gettysburg, 1885]), n.p. Gettysburg National Military Park Library.

"Historic Sites Act of 1935," August 21, 1935 (49 Stat. 666; 16 U.S.C. 461-467). http://www.cr.nps.gov/local-law/FHPL histsites.pdf

Johnston to Superintendent, Gettsyburg National Military Park, July 15, 1940, File No. 207 , Gettysburg, CCF, RG 79.

Memorandum of the Proposed Transfer of Military Parks and Monuments for the Use of the Director in Connection with the Superintendents' Conference as Required by His Memorandum of March 5, 1932, Old History Division Files, WASO

R.L. Jones to Chatelain, June 20, 1934, and Allison to Chatelain, June 18, 1934, Vertical Files, Roads, Avenues, and Rights-of-Way, Folder 3, GNMP Library.

Spalding, Branch. "Flowers to Jackson's Memory," September 1935, copied from The Commonwealth, NO File, Cabinet 7, Drawer 1, FRSP Basement Files.

Spalding, Branch. “Jackson's Fredericksburg Tactics,” Spring 1938, 5, No File, Cabinet 7, Drawer 1, FRSP Basement Files.

Spalding, Branch. Memorandum to Director, Monthly Report for May 1935, June, 8, 1935, 1, File Admin History, Eric Mink Files, FRSP. 
Tilberg, Frederick to Regional Director, Region One, October 3, November 4, and December 3, 1940, File No. 207, Gettysburg, CCF, RG 79; NPS Restoration Policies, May 19, 1937.

Tucker, Annette. “The Gettysburg Reunion,” n.d. V11-62. Gettysburg National Military Park.

U.S. Department of the Interior, National Park Service, Gettysburg National Military Park, "Superintendent's Annual Report for Year 1934-1935," July 27, 1935, James R. McConaghie, Superintendent, pp. 25-29, File No. 207-01, Gettysburg, CCF, RG 79

U.S. Department of the Interior, National Park Service. "Annual Report for the Gettysburg National Military Park, Year Ending September 30, 1934.” James R. McConaghie, Superintendent, pp. 2-8, File No. 207.01, Gettsyburg, CCF, RG 79.

U.S. Department of the Interior, National Park Service, Gettysburg National Military Park, "Superintendent's Annual Report for Year 1936-1937," James R. McConaghie, Superintendent, pp. 7-11, File No. 207-01, Gettysburg, CCF, RG 79.

U.S. Department of the Interior, National Park Service, Gettysburg National Military Park, "Superintendent's Annual Report for Year 1937-1938," James R. McConaghie, Superintendent, pp. 33-34, File No. 207-01, Gettysburg, CCF, RG 79.

U.S. Department of the Interior, National Park Service, Gettysburg National Military Park. “Superintendent's Preliminary Annual Report for Fiscal Year 1939." pp. 14-16, File No. 207-01, Gettysburg, CCF, RG 79.

\section{Oral Histories:}

Interview with Mrs. Hallie Rowley Sale by Donald Pfanz, March 5, 2004. Typescript. BV 546. Fredericksburg and Spotsylvania National Military Park.

Interview with Mrs. R. Taylor Scott by A. Wilson Greene. Date Unknown. Typescript. BV 546. Fredericksburg and Spotsylvania National Military Park.

Interview with Ralph Happel by A. Wilson Greene. 1978. Typescript. BV 545.

Fredericksburg and Spotsylvania National Military Park.

Interview with William Howard by A. Wilson Greene. 1978. Typescript. BV 545.

Fredericksburg \& Spotsylvania National Military Park.

\section{Newspapers:}

“20 G.A.R. Men, Still ‘on Parade,' Get Ovation in Memorial March.” New York Times. May 31, 1934. Proquest Historical Newspapers: Accessed January 18, 2015. 
"21 of G.A.R. March Valiantly in Rain in Tribute to Dead," New York Times, May 31, 1933. ProQuest Historical Newspapers, Accessed January 18, 2015.

“30,000 Race 'Timber Troops' in Anniversary Observance.” New Journal and Guide. April 10, 1937. ProQuest Historical Newspapers, January 12, 2015.

“50,000 Hear President.” New York Times. May 31, 1934. ProQuest Historical Newspapers: Accessed February 20, 2015.

"75th Anniversary, Battle of Gettysburg [0125] - Unveiling of the Eternal Light Peace Memorial :: Civil War Reunions and Reminiscences.” Accessed April 28, 2014. http://gettysburg.cdmhost.com/cdm/singleitem/collection/p15059coll5/id/296/rec/ 125.

“A New Plan for Our Battle Sites.” New York Times. July 22, 1928. ProQuest Historical Newspapers: Accessed January 12, 2015.

“A Virginia Battle Zone Wins Late Recognition.” New York Times. August 30, 1931. ProQuest Historical Newspapers: January 12, 2015.

“A Wide Choice for Readers in the Christmas Book Lists." New York Times. December 2, 1934. Proquest Historical Newspapers: Accessed March 3, 2015.

"Battle Notebooks are Contributed to Park." Fredericksburg Free Lance-Star. October 12, 1942. BV-519. Fredericksburg \& Spotsylvania National Military Park.

“'Bloody Angle' Trenches at Spotsylvania Rebuit.” The New York Times. May 3, 1936. ProQuest Historical Newspapers: Accessed December 1, 2014.

"Books-Authors." New York Times, September 4, 1942. ProQuest Historical Newspapers: Accessed March 3, 2015

Brown, Edgar G. “A Glimpse of a CCC Camp.” The Chicago Defender. June 8, 1935. ProQuest Historical Newspapers: Accessed January 12, 2015.

Cammerer, Arno B. "Parks Look for Big Season." New York Times. April 14, 1935. ProQuest Historical Newspapers: February 20, 2015.

Camp, Edwin. "'Gone with Wind' Stirs the South." New York Times. December 17, 1939. ProQuest Historical Newspapers: Accessed February 5, 2015.

“Colored C.C.C. Men at Camp in Country." Free Lance-Star. August 8, 1934.

"Commemorative Exercises Are Held at Gettysburg." The Pittsburgh Courier. November 18,1936. ProQuest Historical Newspapers: Accessed January 12, 2015.

"Defer Action on Negro C.C.C. Camp." Free Lance-Star. August 4, 1934. 
Dickinson, Leon A. "Motoring In Historic Virginia.” New York Times. April 3, 1932.

ProQuest Historical Newspapers: Accessed January 12, 2015.

Duffus, K.L. “America’s New Symbol of Memorial Day.” New York Times. May 29, 1932. ProQuest Historical Newspapers: Accessed February 20, 2015.

Duffus, R.L. “'The World...Can Never Forget,” New York Times, July 4, 1943. ProQuest Historical Newspapers, March 13, 2015.

"First Colored CCC Commanding Officer Is Appointed." New Journal and Guide. August 15, 1936. ProQuest Histoical Newspapers, January 12, 2015.

“For Fewer Virginia Fetes,” New York Times, July 12, 1936. ProQuest Historical Newspapers, February 24, 2015.

“Gettysburg CCC Co. Gets Park Ready for Celebration.” New Journal and Guide. July 2, 1938. PAIS International: Accessed December 4, 2014.

“Gettysburg Vets Saved Great Democracy for the World.” Philadelphia Record. July 4, 1938. V11-62b. Gettysburg National Military Park.

"Here and There with the Vets." Star and Sentinel. July 9, 1938.

Http://news.google.com/newspapers?id=pYklAAAAIBAJ\&sjid=ufIFAAAAIBAJ $\& p g=11 \% \mathrm{C} 2 \% \mathrm{~A} 0 \% \mathrm{C} 2 \% \mathrm{~A} 0 \% \mathrm{C} 2 \% \mathrm{~A} 0 \% \mathrm{C} 2 \% \mathrm{~A} 0 \% \mathrm{C} 2 \% \mathrm{~A} 0 \% \mathrm{C} 2 \% \mathrm{~A} 0 \% \mathrm{C} 2 \% \mathrm{~A} 0 \%$ $\mathrm{C} 2 \% \mathrm{~A} 0 \% \mathrm{C} 2 \% \mathrm{~A} 0 \% \mathrm{C} 2 \% \mathrm{~A} 0 \% \mathrm{C} 2 \% \mathrm{~A} 0$. Google News Archive.

“Keep the Park As It Is.” Free Lance-Star. June 8, 1933.

"Local Man Promoted to ECW Foremanship." The Pittsburgh Courier. February 15, 1936. ProQuest Historical Newspapers: January 12, 2015.

MacDonald, W.A. “150,000 Hear Him.” New York Times, July 4, 1938. ProQuest Historical Newspapers: Accessed January 12, 2015.

Martin, Paul. "Civil War Vets Hold Last Camp: Two Thousand Men of Blue and Gray Swap Takes in Reunion at Gettysburg"." Rocky Mount Herald. July 1, 1938. V11-62. Gettysburg National Military Park.

McKee, Jr., Oliver. "Highways Unroll Our History.” New York Times. April 19, 1936. ProQuest Historical Newspapers: February 20, 2015.

M'Lean, Charles. “40,000 See Battle of 'Blue and Gray,"” New York Times, May 3, 1935. ProQuest Historical Newspapers: Accessed January 20, 2015. 
"Monument to Stonewall Jackson." Winchester Times. March 2, 1887. BV 492.

Fredericksburg and Spotsylvania National Military Park.

"Nation's War Dead Hailed in Services Here and Abroad," New York Times, May 31, 1939.

ProQuest Historical Newspapers: Accessed January 18, 2015.

"Neglected V.A. Battlefields Hard to Reach By Motor." Fayette Tribune, December 29, 1926.

BV 191. Fredericksburg and Spotsylvania National Military Park.

“President Makes Eloquent Appeal for World Peace." News and Observer. July 4, 1938. V11-62. Gettysburg National Military Park.

"President Will Dedicate Gettysburg Light Today." News and Observer. July 3, 1938. V11-62. Gettysburg National Military Park.

Proctor, Harry G. "Gettysburg Camp Grand Talk Fest for Veterans." The Evening Bulletin. July 1, 1938. V11-62b. Gettysburg National Military Park.

“Railroad Chief Presents Deed.” Free Lance-Star. October 25, 1937. FRSP Lands Files.

“Say Hospitality Rules CCC Camp No. 1355.” Afro-American. May 18, 1940. ProQuest Historical Newspapers, January 12, 2015.

Speers, L.C. "Bill to Aid Tourist." New York Times. February 5, 1939. ProQuest Historical Newspapers: Accessed January 12, 2015.

Story, Isabelle F. "Southward over the 'Battlefield Trail," New York Times, November 7, 1937. ProQuest Historical Newspapers, February 20, 2015.

"Survivors of G.A.R. Pay Tribute to Dead," New York Times, September 6, 1937. ProQuest Historical Newspapers: Accessed January 18, 2015.

"The Blue and Gray: Age Mellows Memories on Seventy-Fifth Gettysburg Anniversary." Newsweek, July 11, 1938. V11-62. Gettysburg National Military Park.

“The President's Address on Parks." New York Times. August 6, 1934. PAIS International: Accessed January 12, 2015.

“"There's Still LIfe in the Old Boys Yet!” The Morning Herald. July 4, 1938. V11-62. Gettysburg National Military Park.

"Thin Ranks of G.A.R. Cling to their Place in Memorial Parade," New York Times, May 31, 1932. ProQuest Historical Newspapers: Accessed January 18, 2015.

“Ultimatum says May Close Camps.” Free Lance-Star. August 7, 1934. 
"Veteran Leaders Plead for Peace: Spirit of Fellowship Prevails at Gettysburg; Woodring Lauds Old-Timers"." News and Observer. July 2, 1938. V11-62. Gettysburg National Military Park.

"Veterans Depart from War Scene: Say Sad Farewells as Their Last Reunion Comes to End at Gettysburg." News and Observer. July 6, 1938. V11-62. Gettysburg National Military Park.

"Veterans Enjoy Army Spectacle: Modern Fighters Stage Spectacular Maneuvers for Heroes at Gettysburg." News and Observer. July 5, 1938. V11-62. Gettysburg National Military Park.

"Visit Gettysburg: Blue and Gray Reunion, 75th Anniversary Battle of Gettysburg 1938." Gettysburg, PA, 1938. V11-62c. Gettysburg National Military Park.

"Want Cannon Ball "To Kill Hitler."" Fredericksburg Free Lance-Star. October 13, 1942. BV519. Fredericksburg \& Spotsylvania National Military Park.

"Woman Fined for Selling Liquor." The Free-Lance Star. BV 492. Fredericksburg and Spotsylvania National Military Park.

Yordan, E.L. "To the Shrines of the Nation.” New York Times. May 26, 1935. ProQuest Historical Newspapers: Accessed February 20, 2015.

"Youths Learn Really How to Live in C.C.C." New Journal and Guide. June 26, 1937. ProQuest Historical Newspapers: Accessed January 12, 2015.

\section{National Archives:}

Records of the Civilian Conservation Corps, Record Group 35

Records of the Works Progress Administration, Record Group 69

Records of the National Park Service, Record Group 79

\section{Secondary Sources:}

Albright, Horace M. As told to Robert Cahn. The Birth of the National Park Service. Salt Lake City, UT: Howe Brothers, 1985.

Blair, William and William Pencak. Making and Remaking Pennsylvania's Civil War. University Park, PA: The Pennsylvania State University Press, 2001. 
Blight, David W. Beyond the Battlefield: Race, Memory, \& the American Civil War. Amherst: University of Massachusetts Press, 2002.

Blight, David W. Race and Reunion: The Civil War in American Memory. Cambridge: Harvard University Press, 2002.

Boym, Svetlana. "Nostalgia and Its Discontents.” In The Collective Memory Reader, edited by Jeffery K. Olick, Vered Vinitzky-Seroussi, and Daniel Levy. New York, N.Y: Oxford University Press, 2011.

Braeman, John, Robert H. Bremner, and David Brody, Editors. The New Deal: The National Level. Columbus: Ohio State University Press, 1975.

Braeman, John, Robert H. Bremner, and David Brody, Editors. The New Deal: The State and Local Levels. Columbus: Ohio State University Press, 1975.

Brinkley, Alan. Culture and Politics in the Great Depression. Waco, TX: Markham Press Fund, 1999.

Brinkley, Alan. The End of Reform: New Deal Liberalism in Recession and War. New York: Alfred A. Knopf, 1995.

Brinkley, Alan. "The New Deal and the Idea of the State," in Fraser and Gerstle, eds.,The Rise and Fall of the New Deal Order, 1930-80. Princeton, NJ: Princeton University Press, 1989.

Childress, Carolyn. “A Grassroots Study of the Civilian Conservation Corps.” BV 513. Fredericksburg \& Spotsylvania National Military Park.

Cohen, Lizabeth. A Consumer's Republic: The Politics of Mass Consumption in Postwar America. New York: Vintage Books, 2004.

Cook, Robert J. Troubled Commemoration: The American Civil War Centennial, 1961-1965. Baton Rouge, LA: Louisiana State University Press, 2007.

Cravens, Hamilton, and Peter C. Mancall, Editors. Great Depression: People and Perspectives. Santa Barbara, CA: ABC-CLIO, 2009.

Cornbiese, Alfred Emile. The CCC Chronicles: Camp Newspapers of the Civilian Conservation Corps, 1933-1942. Jefferson, NC: McFarland \& Co.: 2004.

Dayan, Daniel, and Elihu Katz. "Media Events: The Live Broadcasting of History.” In The Collective Memory Reader, edited by Jeffery K. Olick, Vered Vinitzky-Seroussi, and Daniel Levy. New York, N.Y: Oxford University Press, 2011. 
Desjardin, Thomas A. These Honored Dead: How the Story of Gettysburg Shaped American Memory. Cambridge, MA: Da Capo Press, 2003.

Dickson, Keith Dean. "The Divided Mind of Douglas Southall Freeman and the Transmission of Southern Memory." PhD diss., University of Virginia, 1998.

Everhart, William C. The National Park Service. Westview Library of Federal Departments, Agencies, and Systems. Boulder, Colo: Westview Press, 1983.

Gallagher, Gary W., and Alan T. Nolan, eds. The Myth of the Lost Cause and Civil War History. Bloomington: Indiana University Press, 2000.

Hamby, Alonzo L. For the Survival of Democracy: Franklin Roosevelt and the World Crisis of the 1930s. New York: Free Press, 2004.

Hiltzik, Michael. The New Deal: A Modern History. New York: Free Press, 2011.

Himmelberg, Robert F. The Great Depression and the New Deal. Westport, CT: Greenwood Press, 2001.

Kreiser, Lawrence A., and Randal Allred, eds. The Civil War in Popular Culture: Memory and Meaning. Lexington, Kentucky: University Press of Kentucky, 2014.

Lawson, Alan. A Commonwealth of Hope: The New Deal Response to Crisis. Baltimore: The Johns Hopkins University Press, 2006.

Linenthal, Edward Tabor. Sacred Ground: Americans and Their Battlefields. 2nd ed. Urbana: University of Illinois Press, 1993.

Lowenthal, David. "Identity, Heritage, and Hitory." In Commemorations: The Politics of National Identity, edited by John R. Gillis. Princeton, N.J: Princeton University Press, 1994.

Maher, Neil M. Nature's New Deal: The Civilian Conservation Corps and the Roots of the American Environmental Movement. New York: Oxford University Press, 2008.

Meringolo, Denise D. Museums, Monuments, and National Parks: Toward a New Genealogy of Public History. Amherst: University of Massachusetts Press, 2012.

Murray, Jennifer M. "'Far Above Our Poor Power to Add or Detract: National Park Service Administration of the Gettysburg Battlefield, 1933-1938." Civil War History 55 (March 2009): 56-81.

Murray, Jennifer Marie. On A Great Battlefield': The Making, Management, and Memory of Gettysburg National Military Park, 1933-2013. Knoxville: Unitersity of Tennessee Press, 2014. 
Nash, Gerald D. The Crucial Era: The Great Depression and World War II 1929-1945. New York: St. Martin's Press, 1992.

Paige, John C., and United States. The Civilian Conservation Corps and the National Park Service, 1933-1942: An Administrative History. Washington, D.C.?: National Park Service, U.S. Dept. of the Interior, 1985.

Rauch, Basil. The History of the New Deal 1933-1938. New York: Capricorn Books, 1944.

Salmond, John A. The Civilian Conservation Corps, 1933-1942: A New Deal Case Study. Durham, NC: Duke University Press, 1967.

Shackel, Paul A. Memory in Black and White: Race, Commemoration, and the Post-Bellum Landscape. Walnut Creek, CA: Altamira Press, 2003.

Shaffer, Marguerite S. See America First: Tourism and National Identity, 1880-1940. Washington, D.C.: Smithsonian Institution Press, 2001.

Unrau, Harlan D. “Administrative History: Gettysburg National Military Park and National Cemetery, Pennsylvania.” National Park Service, 1991. http://www.nps.gov/history/history/online_books/gett/adhi.pdf.

Watkins, T.H. The Great Depression: America in the 1930s. Boston: Little, Brown and Company, 1993.

Weeks, Jim. Gettysburg: Memory, Market, and an American Shrine. Princeton, N.J: Princeton University Press, 2003.

Wills, Brian Steel. Gone with the Glory: The Civil War in Cinema. Lanham, Md: Rowman \& Littlefield: Distributed by National Book Network, 2007.

Zenzen, Joan M. At the Crossroads of Preservation and Development: A History of Fredericksburg and Spotsylvania National Military Park. Administrative History. August 2011. 